TINJAUAN ATAS PENYUSUNAN ANGGARAN BELANJA PADA DINAS PERTANIAN

Studi kasus pada Dinas Pertanian Kota Bogor

TUGAS AKHIR

Oleh :

ALVIANTO ALIM SAPUTRA

NRP : 12900092

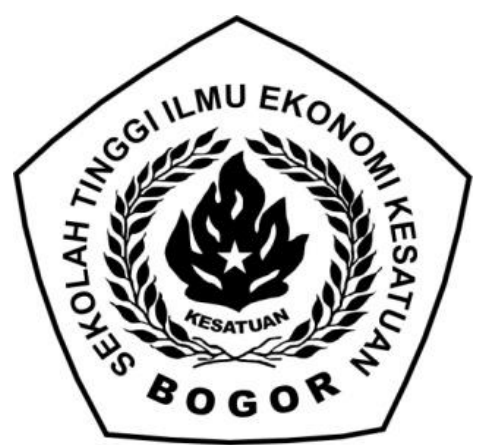

PROGRAM DIPLOMA III AKUNTANSI

SEKOLAH TINGGI ILMU EKONOMI KESATUAN

BOGOR

2015 


\section{TINJAUAN ATAS PENYUSUNAN ANGGARAN BELANJA PADA DINAS PERTANIAN}

Studi kasus pada Dinas Pertanian Kota Bogor

TUGAS AKHIR

Sebagai salah satu syarat untuk memperoleh

Gelar Ahli Madya pada Program Studi Akuntansi

Sekolah Tinggi Ilmu Ekonomi Kesatuan

Oleh :

\section{ALVIANTO ALIM SAPUTRA}

NRP : 12900092

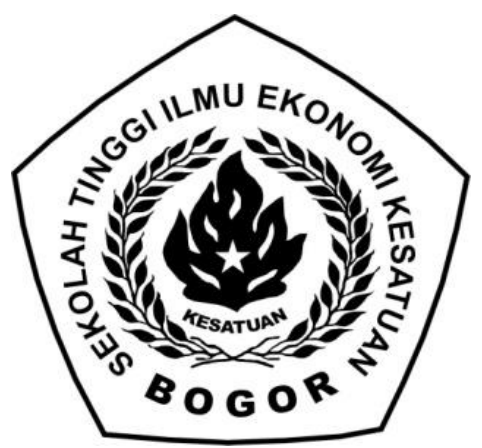

PROGRAM DIPLOMA III AKUNTANSI

SEKOLAH TINGGI ILMU EKONOMI KESATUAN

BOGOR

2015 


\section{TINJAUAN ATAS PENYUSUNAN ANGGARAN BELANJA PADA \\ DINAS PERTANIAN}

Studi kasus pada Dinas Pertanian Kota Bogor

\section{TUGAS AKHIR}

Telah diujikan disetujui pada sidang ahli madya

Sekolah Tinggi Ilmu Ekonomi Kesatuan pada,
Hari
: Sabtu
Tanggal
: 28 Oktober 2015

Mengetahui, 


\section{TINJAUAN ATAS PENYUSUNAN ANGGARAN BELANJA PADA DINAS PERTANIAN}

\section{Studi kasus pada Dinas Pertanian Kota Bogor}

\section{TUGAS AKHIR}

Telah disetujui oleh Pembimbing

Diah Wahyuningsih, SE, M.Ak

Telah diujikan pada sidang Ahli Madya dan dinyatakan LULUS pada tanggal seperti tertera dibawah ini

Bogor, 28 Oktober 2015

Dosen Penguji I

Dosen Penguji II

Hastoni, Ak., MM., CA.

Yayuk Nurjanah, SE., M.Ak 


\begin{abstract}
ABSTRAK
ALVIANTO ALIM SAPUTRA. NPM : 12900092. Tinjauan Atas Penyusunan Anggaran Belanja. Studi Kasus Pada Dinas Pertanian Kota Bogor. Dibawah Bimbingan Diah Wahyuningsih.

Penyusunan anggaran sektor publik di atur dalam Peraturan Walokota Nomor 26 Tahun 2008, tengtang penyusunan anggaran belanja di lingkungan SKPD. Peraturan tersebut berlaku bagi semua organisasi pemerintah dan organisasi sektor publik yang menggunakan anggaran belanja sebagai sumber utama anggaran di setiap kegiatan.

Tujuan peninjauan ini adalah untuk meninjau penyusunan anggaran belanja di instansi pemerintaha yang melakukan penyusunan anggaran belanja setiap tahunnya. Peninjauan dilakukan untuk mengetahui kesesuaian penyusunan anggaran belanja dengan ketentuan yang melandasinya. Peninjauan yang dilakukan penulis adalah di Dinas Pertanian yang berlokasi di Bogor. Dinas Pertanian yang berada di bawah naungan Kementrian Pertanian.

Hasil Peninjauan menunjukan bahwa kantor Dinas Pertanian telah melakukan penyusunan anggaran belanja sesuai dengan ketentuan yang melandasinya. Proses atas penyusunan anggaran belanja yang terjadi dapat dipertanggungjawabkan untuk dijadikan dasar penyusunan anggaran belanja berikutnya. Dalam penyusunan tersebut penyusunan anggaran belanja terjadi tidak mengalamai kekurangan dalam penganggaran belanja yang telah ditetapkan.
\end{abstract}

Keyword : Belanja, Penyusunan Anggaran 


\section{KATA PENGANTAR}

Puji dan syukur penulis panjatkan kepada Allah SWT yang telah melapangkan dengan segala kekuasaannya sehingga tugas akhir ini dapat diselesaikan. Sholawat serta salam penulis ucapkan kepada junjungan besar Nabi Muhammad SAW, Nabi yang selalu penulis jadikan inspirasi dalam perjuangan melawan tatangan kehidupan, tantangan yang tiada henti dalam setiap jalan, tantangan yang bergantian menguji daya juang serta keimanan. Nabi yang mengajarkan penulis sendirilah pengendali kehidupan, buka keluarga, buka kawan, bukan pacar, ataupun mantan.

Materi dalam karya ilmiah ini adalah Akuntansi Sektor Publik, dengan judul "Tinjauan Atas Penyusunan Anggaran Belanja Pada Dinas

Pertanian". Tugas Akhir ini dibuat untuk memenuhi salah satu syarat memperoleh gelar Ahli Madya pada Program Studi Diploma III Akuntansi di Sekolah Tinggi Ilmu Ekonomi Kesatuan Bogor.

Proses penyusunan Tugas Akhir ini sesungguhnya tidak terlepas dari dukungan berbagai pihak. Dalam kesempatan ini penulis menyampaikan terimakasih kepada:

1. Orang tua penulis yang tercinta, Bapak Komarudin dan Ibu Jamilah Tuti, serta adik-adik penulis tersayang atas segala doa dan dukungan kepada penulis selama ini.

2. Ir. Nusa Muktiaji, M.M selaku ketua STIE Kesatuan yang memberi kesempatan kepada penulis untuk menyelesaikan pendidikan.

3. Yayuk Nurjanah, SE., M.Ak selaku ketua program studi akuntansi yang telah membantu penulis dalam berbagai hal.

4. Diah Wahyuningsih, SE selaku pembimbing yang telah dengan sabar meluanhkan waktunya untuk memberikan masukan dan arahan kepada penulis.

5. Domes serta tenaga pengajar STIE Kesatuan Bogor yang telah memberi banyak ilmu yang bermanfaat.

6. Segenap Staff BAAK, Keuangan, BAUM, Perpustakaan, serta SekJur STIE Kesatuan Bogor yang membantu penulis dalam berbagai hal.

7. Keluarga besar Dinas Pertanian yang telah membantu penulis dalam pengambilan data untuk baha tugas akhir.

8. Teman sekelas D3 Akuntansi Karyawan serta pagi yang selalu menemani dan menjadi sahabat penulis baik di dalam kampus maupun luar kampus. 
Sebagai manusia biasa, penulis menyadari bahwa Tugas Akhir ini masih jauh dari kata sempurna. Sehingga debgan segala kerendahan serta ketulusan hati penulis senantiasa menerima segala kritik dan saran yang bersifat membangun demi penyempurnaan dimasa datang.

Akhir kata penulis berharap semoga Tugas Akhir ini dapat memberikan manfaat dan pengetahuan khususnya bagi penulis dan umumnya bagi seluruh mahasiswa dan atau mahasiswi STIE Kesatuan Bogor serta pihak lain yang membutuhkan.

Bogor, September 2015

Penulis

Alvianto Alim

Saputra 
DAFTAR ISI

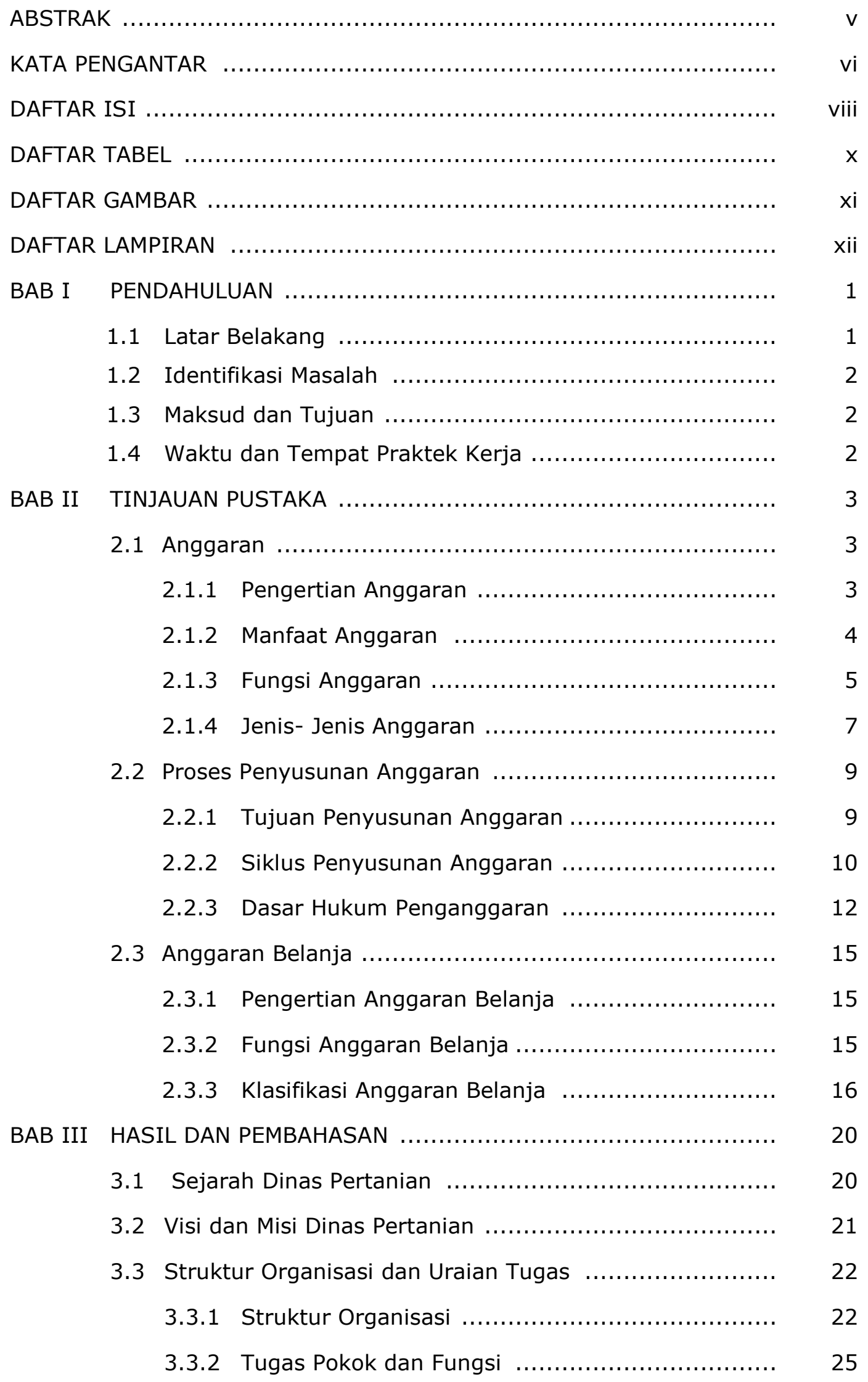


3.4 Sumber Daya Manusia.................................... $\quad 34$

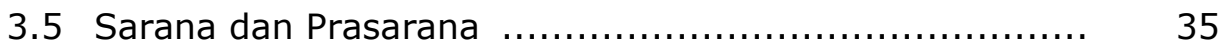

3.6 Uraian Singkat Kegiatan Magang $\ldots \ldots \ldots \ldots \ldots \ldots \ldots \ldots \ldots \ldots . . . \ldots \ldots$

3.7 Perbandingan Teori dan Praktek $\ldots \ldots \ldots \ldots \ldots \ldots \ldots \ldots \ldots \ldots \ldots \ldots \ldots \ldots \ldots$

3.7.1 Proses Penyusunan Anggaran Belanja pada Dinas

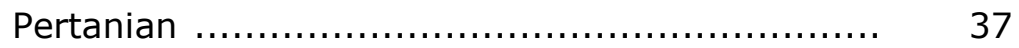

3.7.2 Dasar Dalam Penyusunan Anggaran Belanja Pada

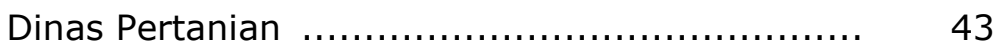

3.7.3 Kesesuaian Anggaran Belanja Pada Dinas Dengan Ketentuan yang Melandasinya $\ldots \ldots \ldots \ldots \ldots \ldots \ldots \ldots . . . \ldots \ldots$

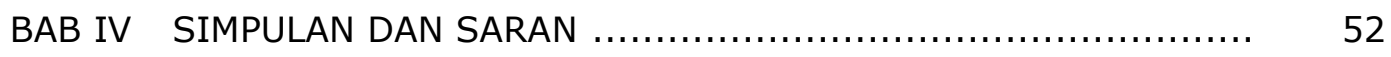

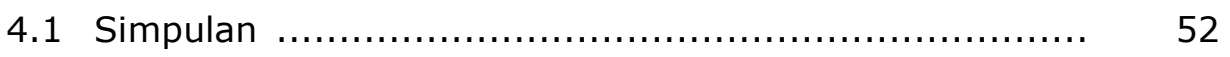

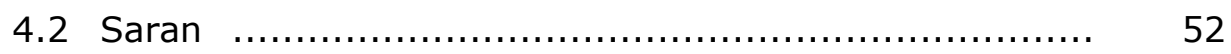

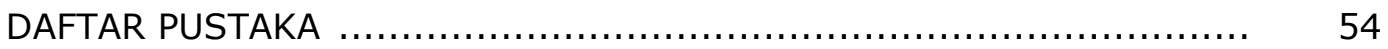

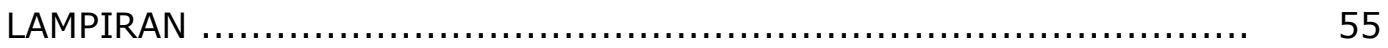




\section{DAFTAR TABEL}

Nomor

Teks

Halaman

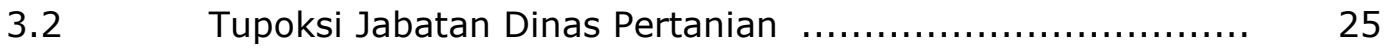

3.3 Keadaan Pegawai Dinas Pertanian Kota Bogor …............ 35

3.4 Anggaran dan Realisasi Belanja Dinas Pertanian ............. 47

3.5 Anggaran Belanja Tidak Langsung Dinas Pertanian ......... 48

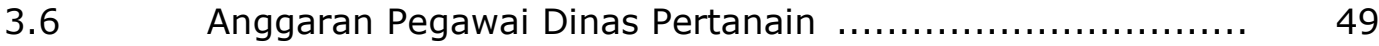




\section{DAFTAR GAMBAR}

Nomor

Teks

Halaman

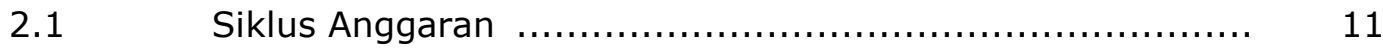

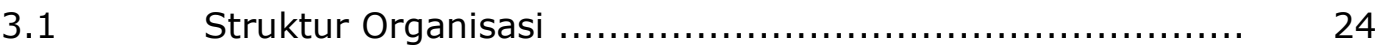

3.2 Keterkaitan antara Renja SKPD, Renstra dan Dokumen

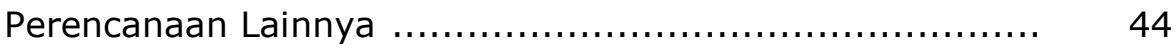


DAFTAR LAMPIRAN 


\section{BAB I}

\section{PENDAHULUAN}

\subsection{Latar Belakang}

Anggaran belanja merupakan bagian penting dalam kegiatan operasional dinas atau lembaga daerah, hal ini terkait dengan pembiayaan kegiatan yang ada pada dinas atau lembaga daerah. Oleh karena itu penyusunan Anggaran Belanja harus berjalan efektif dan efisien dengan memperhatikan ketentuan-ketentuan tentang pelaksanaannya dan dapat menjelaskan biaya-biaya yang dibebankan kepada masing-masing kegiatan yang dilakukan oleh dinas atau lembaga daerah tersebut. Suatu anggaran belanja harus saling mendukung antara rencana kerja dan kegiatan dalam dinas atau lembaga daerah. Dalam penyusunan anggaran Belanja diperlukan prosedur penyusunan yang sesuai dengan kebijakan yang ditetapkan.

Dalam proses penyusunan anggaran masih sering terjadi tidak adanya dana bagi suatu kegiatan yang semestinya dijalankan. Salah satu contoh sederhananya adalah tidak dialokasikannya dana yang cukup untuk pemeliharaan sarana dan prasarana suatu kantor atau dinas tertentu, yang dalam kenyataannya dana pemeliharaan tersebut merupakan hal yang sangat diperlukan agar oprasional berjalan dengan baik dan semestinya. Hal tersebut merupakan indikasi bahwa masih adanya kelemahan dalam penyusunan anggaran belanja suatu departemen atau dinas tertentu. Lemahnya dalam perencanaan penyusunan anggaran belanja juga dapat berakibat melemahkan kinerja pemerintah.

Penelitian mengenai penyusunan anggaran belanja telah dilakukan oleh Rere Hardyan Muchtar (2014). Yang menyimpulkan bahwa Inspektorat Jendral Kementrian Pariwisata dan Ekonomi Kreatif sudah melakukan penyusunan anggaran dengan cukup baik, namun dalam proses penyusunan anggaran terkadang masih mengalami hambatan karena sesekali sering muncul peraturan-peraturan baru yang menjadi acuan baru untuk proses penyusunan anggaran.

Berdasarkan permasalahan dan penelitian sebelumnya penulis tertarik untuk melakukan pengkajian lebih jauh tentang penyusunan anggaran belanja pada dinas pertanian dengan mengambil data pada tahun 2014. Penulis tertarik mengangkat judul "Tinjauan Atas Penyusunan Anggaran 
Belanja Pada Dinas Pertanian". Dengan melakukan kerja praktek pada Dinas Pertanian (Distani) untuk mengetahui penyusunan anggaran belanja.

\subsection{Identifikasi Masalah}

Berdasarkan latar belakang tersebut maka penulis mengidentifikasikan masalah sebagai berikut :

1. Bagaimana penyusunan anggaran belanja pada Dinas Pertanian?

2. Apakah yang menjadi dasar dalam pelaksanaan penyusunan anggaran pada Dinas Pertanian?

3. Bagaimana kesesuaian proses penyusunan anggaran pada Dinas Pertanian?

\subsection{Maksud dan Tujuan}

Adapun maksud dari tugas akhir ini adalah untuk mengetahui bagaimana penyusunan anggaran pada Dinas Pertanian serta untuk memenuhi gelar Ahli Madya Akuntansi. Sedangkan Tujuan dari penulisan Tugas Akhir ini adalah sebagai berikut :

1. Untuk mengetahui penyusun anggaran belanja pada Dinas Pertanian.

2. Untuk mengetahui dasar dalam pelaksanaan penyusunan anggaran pada Dinas Pertanian.

3. Untuk mengetahui kesesuaian proses penyusunan anggaran pada Dinas Pertanian.

\subsection{Waktu dan Tempat Praktek Kerja}

Dalam pembuatan tugas akhir ini penulis melakukan praktek kerja disalah satu instansi pemerintahan di bawah naungan Kementrian Pertanian yaitu di Dinas Pertanian Kota Bogor (DISTANI). Dinas Pertanian Beralamat di Jl. Cipaku no. 5 kelurahan cipaku.

Waktu dan pelaksaan kerja praktek ini dilakukan selama 2 bulan dimulai dari tanggal 30 Maret 2015 sampai 30 Mei 2015. Sedangkan jadwal kegiatan kerja yang dilaksanakan dimulai pukul 08.00 - 15.30. Kegiatan kerja diawali dari hari Senin sampai Jumat. Penulis mengambil data seperti sejarah Dinas Pertanian, visi dan misi Dinas Pertanian, struktur organisasi, tugas pokok dan fungsi dari Dinas Pertanian dan Jabatan dan lain-lain. 


\section{BAB II}

\section{TINJAUAN PUSTAKA}

\subsection{Anggaran}

\subsubsection{Pengertian Anggaran}

Penganggaran sektor publik terkait dengan proses penentuan jumlah alokasi dana untuk tiap-tiap program dan aktivitas dalam satuan moneter, seperti yang dijelaskan oleh Mulyadi (2007 : 488) anggaran merupakan suatu rencana kerja yang dinyatakan kuantitatif, yang diukur dalam satuan moneter standar dan satuan ukuran yang lain yang mencakup jangka waktu satu tahun. Anggaran menjadi sangat penting bagi suatu organisasi karena rencana yang tertulis mengenai kegiatan yang dinyatakan secara keantitatif dan umumnya dalam satuan uang untuk jangka waktu tertentu M. Nafarin (2009: 12).

The National Committe on Governmental Accounting di dalam buku Abdul Halim (2007 : 14) mendefinisikan anggaran sebagai "A Budget is plan of financial operation embodying an estimated of proposed expenditures for a given period of time and the proposed means of financing them". Maksudnya anggaran adalah rencana kegiatan yang diwujudkan dalam bentuk finansial, meliputi usulan pengeluaran yang diperkirankan untuk suatu periode waktu, serta usulan cara-cara memenuhi pengeluaran tersebut. Anggaran juga rencana yang disusun secara sistematis, yang meliputi seluruh kegiatan perusahaan, yang dinyatakan dalam unit (satuan) moneter dan berlaku untuk jangka waktu tertentu dimasa yang akan datang, Munandar (2007 : 1). Rencana kerja operasional yang dinyatakan dalam satuan uang dari suatu organisasi, dimana disitu pihak menggambarkan perkiraan pendapatan ataupenerimaan guna menutupi pengeluaran tersebut, untuk periode yang umumnya periode 1 (satu) tahun, Abdul Halim (2007 : 320)

Dari beberapa rumusan pengertian diatas, anggaran dapat diartikan pula sebagai suatu rencana yang disusun secara sistematis dalam bentuk angka dan dinyatakan dalam unit moneter dan rencana yang meliputi seluruh kegiatan perusahaan atau pemerintahan untuk waktu tertentu dimasa yang akan datang untuk jangka waktu tertentu. Anggaran juga harus bersifat sistematis, maksudnya anggaran harus disusun secara berurutan. 


\subsubsection{Manfaat Anggaran}

Tidak semua aspek kehidupan masyarakat tercakup oleh anggaran sektor publik. Terdapat beberapa aspek kehidupan yang tidak tersentuh oleh anggaran sektor publik, baik skala nasional maupun lokal. Anggaran sektor publik dibuat untuk membantu menentukan tingkat kebutuhan masyarakat, seperti listrik, air bersih, kualitas kesehatan, dan lain-lain.

Aliran dana yang terkait aktivitas pemerintahan atau perusahaan akan mempengaruhi harga, lapangan pekerjaan, distribusi pendapatan, pertumbuhan ekonomi, dan beban pajak yang harus dibayar atas pelayanan yang diberikan pemerintahan.

Menurut Mardiasmo (2008: 63) anggaran sektor publik penting karena beberapa alasan, sebagai berikut :

1. Anggaran merupakan alat bagi pemerintahan untuk mengarahkan pembangunan sosial ekonomi, menjamin kesinambungan, dan meningkatkan kualitas hidup masyarakat.

2. Anggaran diperlukan karena adanya kebutuhan dan keinginan masyarakat yang tak terbatas dan terus berkembang, sedangkan sumber daya yang ada terbatas. Anggaran diperlukan karena adanya masalah keterbatasan sumber data (scarcity of resouces), pilihan (choice), dan trade offs.

3. Anggaran diperlukan untuk menyakinkan bahwa pemerintah telah bertanggung jawab terhadap rakyat. Dalam, hal ini anggaran publik merupakan instrumen pelaksanaan akuntabilitas oleh lembaga-lembaga publik yang ada.

Anggaran juga mempunyai manfaat seperti yang dikemukakan oleh nafarin (2009: 19), yaitu :

1. Segala kegiatan dapat terarah pada pencapaian tujuan bersama

2. Dapat digunakan sebagai alat menilai kelebihan dan kekurangan pegawai

3. Dapat memotovasi pegawai

4. Menimbulkan rasa tanggungjawab pada pegawai

5. Mengindari pemborosan pembayaran yang kurang perlu

6. Sumber daya, seperti tenaga kerja, peralatan, dan dana dapat dimanfaatkan seefisien mungkin

7. Alat pendidikan bagi para manajer atau pemimpin. 


\subsubsection{Fungsi Anggaran}

Menurut Deddi Nowdiawan (2010 : 64) anggaran mempunyai beberapa macam fungsi antara lain :

1. Anggaran sebagai alat perencanaan

Anggaran merupakan alat perencanaan manajemen untuk mencapai tujuan organisasi. Anggaran sektor publik dibuat untuk merencanakan tindakan apa yang akan dilakukan oleh pemerintah, beberapa biaya yang dibutuhkan, dan beberapa hasil yang diperoleh dari belanja pemerintah tersebut.

Anggaran sebagai alat perencanaan digunakan untuk :

a. Merumuskan tujuan serta sasaran kebijakan agar sesuai dengan visi dan misi yang ditetapkan.

b. Merencanakan berbagai program dan kegiatan untuk mencapai tujuan organisasi serta merencanakan alternative sumber pembiayaannya.

c. Mengalokasikan dana pada berbagai program kegiatan yang telah disusun.

d. Menentukan indikator kinerja dan tingkat pencapaian strategi.

2. Anggaran sebagai alat pengendalian

Sebagai alat pengendalian, anggaran memberikan rencana detail atas pendapatan dan pengeluaran pemerintah agar pembelanjaan yang dilakukan dapat dipertanggung jawabkan kepada publik. Tanpa anggaran, pemerintah tidak dapat mengendaliakan pemborosan-pemborosan pengeluaran. Bahkan tidak berlebihan jika dikatakan bahwa presiden, menteri, gubernur, bupati, dan manajer publik lainnya dapat dikendalikan melalui anggaran. Anggaran sektor publik dapat digunkan untuk mengendalikan (membatasi kekuasaan) eksekutif.

3. Anggaran sebagai alat kebijakan

Anggaran digunakan untuk menstabilkan ekonomi dan mendorong ekonomi. Melalui anggaran publik tersebut dapat diketahui arah kebijakan fiskal pemerintah, sehingga dapat dilakukan prediksi-prediksi dan estimasi ekonomi. Selain itu digunakan untuk mendorong, memfasilitasi, dan mengkoordinasikan kegiatan ekonomi masyarakat sehingga dapat mempercepat pertumbuhan ekonomi.

4. Anggaran sebagai alat politik

Anggaran digunakan untuk memutuskan prioritas-prioritas dan kebutuhan keuangan terhadap prioritas tersebut. Anggaran merupakan dokumen 
politik sebagai bentuk komitmen eksekutif dan kesepakatan legislatif atas penggunaan dana publik untuk kepentingan tertentu. Oleh karena itu, pembuatan anggaran publik membutuhkan political skill, coalition bilding, keahlian bernegosiasi, dan pemahaman tentang prinsip manajemen keuangan publik. Manajer publik harus sadar sepenuhnya bahwa kegagalan dalam melaksanakan anggaran yang telah disetujui dapat menjatuhkan kepemimpinannya, atau paling tidak menurunkan kredibilitas pemerintahan.

5. Anggaran sebagai alat koordinasi dan komunikasi

Anggaran publik merupakan alat koordinasi antar bagian dalam pemerintahan. Anggaran publik yang disusun dengan baik akan mampu mendeteksi terjadinya inkonsistensi suatu unit kerja dalam pencapaian tujuan organisasi. Disamping itu, anggaran publik juga berfungsi sebagai alat komunikasi antar unit kerja dalam lingkungan eksekutif. Anggaran harus dikomunikasikan ke seluruh bagian organisasi untuk dilaksanakan.

6. Anggaran sebagai alat penilaian kerja

Anggaran merupakan wujud komitmen dari budget holder (eksekutif) kepada pemberi wewenang (legislatif). Kinerja eksekutif akan dinilai berdasarkan pencapaian target anggaran dan efisiensi pelaksanana anggaran. Kinerja manajer publik dinilai berdsarkan berapa yang berhasil ia capai dikaitkan dengan anggaran yang telah ditetapkan. Anggaran meruoajan alat yang efektif untuk pengendalian dan penialian kinerja.

7. Anggaran sebagai alat motivasi

Anggaran dapat digunakan sebagai alat komunikasi dengan menjadikan nilai-nilai nominal yang tercantum sebagai target pencapaian. Dengan catatan, anggaran akan menjadi alat motivasi yang baik jika memenuhi sifat "menantang". Tetapi masih mungkin dicapai.

8. Anggaran sebagai alat untuk menciptakan ruang publik Anggaran publik tidak boleh diabaikan oleh kabinet, birokrat, dan DPR/DPRD. Masyarakat, LSM, perguruan tinggi, dan berbagai organisasi kemasyarakatan harus terlibat dalam proses penganggaran publik. Kelompok masyarakat yang terorganisir akan mencoba mempengaruhi anggaran pemerintah untuk kepentingan mereka. Kelompok lain dari masyrakat yang kurang terorganisasi akan mempercayakan aspirasinya melalui proses politik yang ada. Pengangguran, tuna wisma dan kelompok lain yang tak terorganisasi akan mudah dan tidak berdaya mengikuti tindakan pemerintah. Jika tidak ada alat untuk menyampaikan suara 
mereka, maka mereka akan mengambil tindakan dengan jalan lain seperti dengan tindakan massa, melaukan boikot, vandalisme, dan sebagainya. Sedangkan menurut Indra Bastian (2007 : 164) fungsi anggaran meliputi:

1. Anggaran merupakan hasil akhir proses penyusunan rencana kerja,

2. Anggaran merupakan cetak biru aktivitas yang akan dilaksanakan di masa mendatang,

3. Anggaran sebagai alatkomunikasi intern yang menghubungkan berbagai unit kerja dan mekanisme kerja anatar atasan dan bawahan,

4. Anggaran sebagai alat pengendalian unit kerja,

5. Anggaran sebagai alat motivasi dan persuasi tindakan efektif dan efisien dalam pencapaian visi organisasi,

6. Anggaran merupakan instrumen politik,

7. Anggaran merupakan instrumen kebijakan fiskal.

\subsubsection{Jenis-jenis Anggaran}

Di samping manfaat dan dan fungsi anggaran perlu juga diperhatikan masalah klasifikasi anggaran. Yang dimaksud klasifikasi anggaran adalah pengelompokan dan pembagian anggaran untuk dapat memberikan gambaran yang terperinci dari anggaran secara keseluruhan.

Menurut Muhammad Gade (2005 : 43) Klasifikasi anggaran yang utama dapat dibagi menjadi dalam empat jenis yaitu :

a. Klasifikasi organik, yaitu pengelompokan anggaran menurut unit organisasi, misalnya untuk departemen/lembaga tertentu dan menunjuk seorang yang bertanggung jawab untuk unit tersebut,

b. Klasifikasi Fungsional, yaitu pengelompokan anggaran menurut tugastugas yang sama sesuai dengan fungsi tertentu misalnya pengeluaran untuk pendidikan dijadikan satu kelompok,

c. Klasifikasi ekonomis, yaitu pengelompokan anggaran untuk memberikan gambaran tentang kebijakansanaan pemerintah di bidang ekonomi.

d. Klasifikasi objek, yaitu pengelompokan anggaran untuk tiap unit menurut kegiatan tertentu, misalnya anggaran puntuk proyek. 
Deddi Nordiawan (2010 : 50) mengemukakan bahwa anggaran dibagi menjadi 5 (lima) bagian, yaitu:

1. Berdasarkan aktivitasnya anggaran dibagi menjadi dua, yaitu :

a. Anggaran Operasional (current budget) digunakan untuk merencanakan kebutuhan dalam menjalankan operasi sehari-hari dalam kurun waktu satu tahun. Anggaran operasional ini juga sering dikelompokan sebagai pengeluaran pendapatan (revenue expenditure), yaitu jenis pengeluaran yang bersifat rutin dan jumlahnya kecil serta tidak menambah fungsi suatu aset.

b. Anggaran Modal (capital budget) menunjukan rencana jangka panjang dan pembelanjaan atas aktiva tetap, seperti gedung, peralatan, kendaraan, perabot, dan sebagainya. Belanja modal adalah pengeluaran yang manfaatnya cenderung melebihi satu tahun anggaran dan akan menambah jumlah aset atau kekayaan organisasi sektor publik, yang selanjutnya akan menambah anggaran operasional untuk pemeliharaannya.

2. Berdasarkan status hukum, anggaran dibagi menjadi :

a. Anggaran tentatif adalah anggaran yang tidak memerlukan pengesahan dari lembaga legislatif karena kemunculannya yang dipicu oelh hal-hal yang tidak direncanakan sebelumnya.

b. Anggaran enacted adalah anggaran yang direncanakan, kemudian dibahas dan disetujui oleh lembaga legislatif.

3. Berdasarkan kekayaan negara, anggaran dibagi menjadi :

a. Anggaran dana umum digunakan untuk membiayai kegiatan pemerintahn yang bersifat umum dan sehari-hari.

b. Dana khusus dicadangkan / dialokasikan khusus untuk tujuan tertentu, misalnya debt service fund yang digunakan khusus untuk pembayaran utang.

4. Bedasarkan jumlahnya, anggaran dibagi menjadi :

a. Anggaran tetap apropriasi belanja sudah ditentukan jumlahnya di awal tahun anggaran. Jumlah tersebut tidak boleh dilampaui meskipun ada peningkatan jumlah kegiatan yang dilakukan.

b. Dalam anggaran fleksibel, harga barang / jasa per unit telah ditetapkan. Namun lembaga ekseku, jumlah anggaran secara keseluruhan akan berfluktuasi bergantung pada banyaknya kegiatan yang dilakukan. 
5. Berdasarkan Penyusunannya, anggaran dibagi menjadi :

a. Anggaran eksekutif yaitu anggaran yang disusun oleh lembaga eksekutif, dalam hal ini pemerintah.

b. Anggaran legislatif yaitu anggaran yang disusun oleh lembaga legislatif tanpa melibatkan pihal eksekutif.

c. Anggaran bersama (join budget) yaitu anggaran yang disusun bersama-sama antara lembaga eksekutif dan legislatif.

Sebagai sebuah sistem, perencanaan anggaran juga telah mengalami banyak perkembangan. Sistem perencanaan anggaran berkembang dan berubah sesuai dengan dinamika perkembangan manajemen sektor publik dan perkembangan tuntutan yang muncul dimasyarakat. Mardiasmo (2009 : 66-67) mengemukakan bahwa anggaran sektor publik dibagi menjadi 2 (dua), yaitu:

\section{Anggaran Operasional}

Anggaran operasional digunakan untuk merencanakan kebutuhan seharihari dalam menjalankan pemerintahan. Pengeluaran pemerintah yang dapat dikategorikan dalama anggaran operasional adalah "belanja rutin". Belanja rutin (recurrrent expenditure adalah pengeluaran yang manfaatnya hanya satu tahun anggaran dan tidak dapat menambah asset atau kekayaan bagi pemerintah. Disebut "rutin" krena sifat pengeluaran tersebut berulang-ulang ada setiap tahun. Secara umum, pengeluaran yang masuk kategori anggaran operasional antara lain belanja administrasi umum dan belanja operasi dan pemeliharaan.

2. Anggaran Modal / Investasi

Anggaran modal menunjukan rencana jangka panjang dan pembelanjaan atas aktiva tetap seperti gedung, peralatan, kendaraan, perabot, dan sebagainya. Pengeluaran modal yang besar biasanya dilakukan dengan menggunakan pinjaman. Belanja investasi/modal adalah pengeluaran yang manfaatnya cenderung melebihi 1 (satu) tahun anggaran dan akan menambah asset atau kekayaan pemerintah, dan selanjutnya akan menambah anggaran rutin untuk biaya operasional dan pemeliharaannya. 


\subsection{Proses Penyusunan Anggaran}

\subsubsection{Tujuan Penyusunan Anggaran}

Anggaran yang dipresentasikan setiap tahun oleh eksekutif, memberi informasi rinci kepada DPR/DPRD dan masyrakat tentang program-program apa yang direncanakan pemerintah untuk meningkatkan kualitas kehidupan rakyat, dan bagaimana program-program tersebut dibiayai. Penyusunan dan pelaksanaan anggaran tahunan merupakan rangkaian proses anggaran. Proses anggaran menurut mardiasmo (2008 : 68-69) mempunyai empat tujuan, yaitu :

1. Membantu pemerintah mencapai tujuan fiskal dan meningkatkan koordinasi antar begian dalam lingkungan pemerintah,

2. Membantu mencciptakan efisiensi dan keadilan dalam menyediakan barang dan jasa publik melalui proses pemrioritasan,

3. Memungkinkan bagi pemerintah untuk memenuhi prioritas belanja dan,

4. Meningkatkan transparasi dan pertanggungjawaban pemerintah kepada DPR/DPRD dan masyarakat luas.

Faktor dominan yang terdapat dalam proses penyusunan penganggaran adalah sebagai berikut :

1. Tujuan dan target yang hendak dicapai.

2. Ketersediaan sumber daya (faktor-faktor produksi yang dimiliki pemerintah).

3. Waktu yang dibutuhkan untuk mencapai tujuan target.

4. Faktor-faktor lain yang mempengaruhi anggaran, seperti : munculnya peraturan pemerintah yang baru, fluktuasi pasar, perubahan sosial politik, bencana alam, dan sebagainya.

Sedangkan Menurut Abdul Halim dan Muhammad iqbal (2012 : 126) fungsi penyusunan anggaran yaitu :

1. Menentukan penerimaan dan pengeluaran.

2. Membantu dalam membuat kebijakan dan perencanaan.

3. Mengesahkan pengeluaran yang akan datang

4. Menjadikan dasar pengendalian pendapatan dan pengeluaran.

5. Sebabagi standar dalam evaluasi kerja.

6. Sebagai motivasi manager dan karyawan.

7. Mengkoordinir kegiatan dari berbagai macam tujuan. 


\subsubsection{Siklus Penyusunan Anggaran}

Dalam penyusunan anggaran prinsip-prinsip pokok siklus anggaran perlu diketahui dan dikuasai dengan baik oleh pemerintah. Menurut mardiasmo (2008 : 67) ada delapan prinsip-prinsip anggaran sektor publik, meliputi :

1. Otorisasi oleh legislatif, Anggaran publik harus mendapatkan otorisasi dan kegislatif terlebih dahulu sebelum eksekutif dapat membelanjakan anggaran tersebut.

2. Komprhensif, Anggaran harus menunjukan semua penerimaan dan pengeluaran pemerintahan. Oleh karena itu, adanya non-budgetair (tidak dianggarkan) pada dasarnya menyalahi prinsip anggaran yang bersifat komprehensif.

3. Keutuhan anggaran, Semua penerimaan dan belanja pemerintah harus terhimpun dalam dana umum (general fund).

4. Nondiscretionary Appropriation, Jumlah yang disetujui oleh dewan legislatif harus termanfaatkan secara ekonomis, efisien, dan efektif.

5. Periodik, Jumlah merupakan suatu proses yang periodik, dapat bersifat tahunan maupun multi-tahunan.

6. Akurat, Estimasi anggaran hendaknya tidak memasukkan cadangan yang tersembunyi yang dapat dijadikan sebagai kantong-kantong pemborosan dan inefisiensi anggaran serta dapat mengakibatkan munculnya underestimate pendapatan dan overestimate pengeluaran.

7. Jelas, Anggaran hendaknya sederhana, dapat dipahami masyarakat, dan tidak membingungkan.

8. Diketahui publik, Anggaran harus diinformasikan kepada masyarakat luas.

Pembuatan anggaran adalah suatu proses yang berkelanjuatan. Pada organisasi sektor publik, menurut nordiawan (2006 : 52) pembuatan anggaran umumnya melewati lima tahapan, yaitu: 


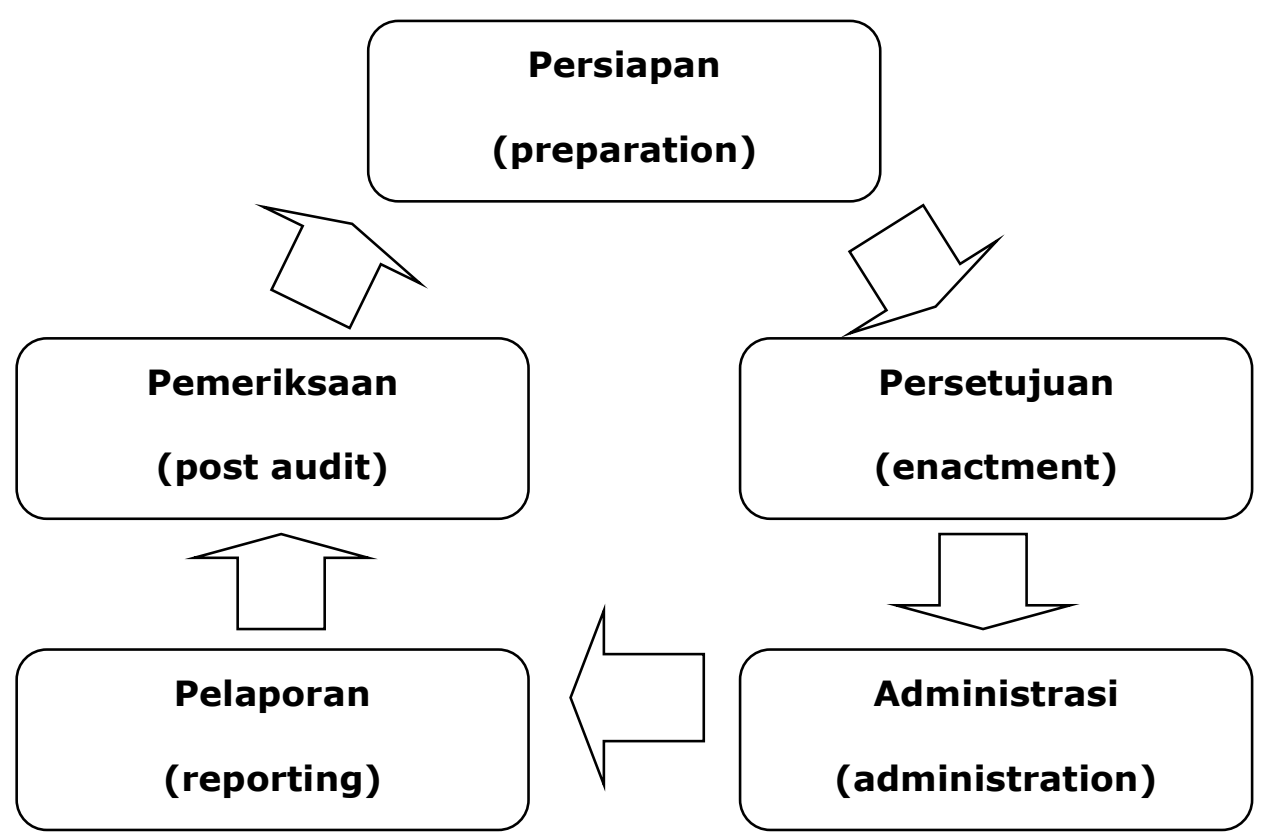

GAMBAR 2.1

Siklus anggaran

1. Persiapan (preparation)

Pada tahap persiapan, bagian anggaran menyiapkan format anggaran yang akan dipakai. Kemudian masing-masing unit di pemerintahan mengajukan anggaran yang selanjutnya akan dikonsolidasikan oleh bagian anggaran. Setelah ditelaah dan diadakan dengar pendapat ke semua unit, anggaran ini akan disetujui oleh kepala pemerintahan.

2. Persetujuan Lembaga Legislatif

Anggaran diajukan ke lembaga legislatif untuk mendapatkan persetujuan. Dalam hal ini, lembaga legislatif (terutama komite anggaran) akan mengadakan pembahasan guna memperoleh pertimbangan-pertimbangan untuk menyetujui atau menolak anggaran tersebut. Selain itu, akan diadakan juga dengar pendapat sebelum nantinya lembaga legislatif menyetujui atau menolaknya.

3. Administrasi

Setelah anggaran disahkan, pelaksanaan anggaran dimulai baik pengumpulan pendapatan yang ditargetkan maupun pelaksanaan belanja yang telah direncanakan. Bersamaan dengan tahap pelaksanaan ini dilakukan pula proses administrasi anggaran yang meliputi pencatatan pendapatan dan belanja yang terjadi.

4. Pelaporan

Pada akhir periode atau pada waktu-waktu tertentu yang ditetapkan dilakukan pelaporan sebagai bagian yang tak terpisahkan dari proses akuntansi yang telah berlangsung selama proses pelaksanaan. 


\section{Pemeriksaan}

Laporan yang diberikan atas pelaksanaan anggaran kemudian diperiksa oleh lembaga pemeriksaan independen. Hasil pemeriksaan akan menjadi masukan atau umpan balik untuk proses penyusunan pada periode berikutnya.

\subsubsection{Dasar Hukum Penganggaran}

Penganggaran di Indonesia secara umum sudah di atur dalam konstitusi suatu negara, peraturan perundang-undangan, atau dalam akuntansi pemerintah :

\section{Undang-undang No. 17 Tahun 2003, Tentang Keuangan Negara}

Ketentuan mengenai penyusunan dan penetapan APBN/APBD dalam undang-undang ini meliputi penegasan tujuan dan fungsi penganggaran pemerintah, penegasan peran DPR/DPRD dan pemerintah dalam proses penyusunan dan penetapan anggaran, pengintegrasian sistem akuntabilitas kinerja dalam sistem penganggaran, penyempurnaan klasifikasi anggaran, penyatuan anggaran, dan pengunaan kerangka pengeluaran jangka menengah dalam penyusunan anggaran. Anggaran adalah alat akuntabilitas, manajemen, dan kebijakan ekonomi. Sebagai instrumen kebijakan ekonomi anggaran berfungsi untuk mewujudkan pertumbuhan dan stabilitas perekonomian serta pemerataan pendapatan dalam rangka mencapai tujauan bernegara. Dalam upaya untuk meluruskan kembali tujuan dan fungsi anggaran tersebut perlu dilakukan peraturan secara jelas peran DPR/DPRD dan pemerintah dalam proses penyusunan dan penetapan anggaran sebagai penjabaran aturan pokok yang telah ditetapkan dalam undang-undang dasar 1945. Sehubungan dengan itu, dalam undang-undang ini disebutkan bahwa belanja negara atau belanja daerah dirinci sampai dengan unit organisasi, fungsi program, kegiatan dan jenis belanja. Hal tersebut berarti bahwa setiap pergeseran anggaran antara unit organisasi, dan anatara jenis belanja harus mendapat persetujuan DPR/DPRD.

2. Undang-Undang No. 1 Tahun 2004, Tentang Pembendaharaan Negara

Undang Nomor 1 Tahun 2004 tentang perbendaharaan negera yang merupakan ketentuan pelaksanaan sebagai tinjak lanjut atas disahkannya Undang-Undang No. 17 Tahun 2003. Menurut Undang-Undang No.1 Tahun 2004 tersebut, yang dimaksud dengan Perbendaharaan Negara 
adalah pengelolaan dan pertanggungjawaban keuangan negara, termasuk investasi dan kekayaan yang dipisahkan, yang ditetapkan dalam APBN dan APBD. Seiring dengan konsep di atas, pelaksanaan anggaran dilakukan melalui pembagian tugas antara Menetri Keuangan selaku pemegang kewenangan kebendaharaan dengan Menteri negara atau lembaga selaku pemegang kewenangan adminitratif.

Dalam penjelasan Umum Undang-Undang No.1 Tahun 2004 dijelaskan bahwa kewenangan untuk melakukan perikatan atau tindakan lain yang mengakibatkan terjadinya penerimaan atau pengeluran negara, kewenangan melakukan pengujian dan pembebanan tagihan yang diajukan kepada menteri negara atau lembaga sehubungan dengan realisasi perikatan tersebut, serta memerintahkan pembayaran atau menagih penerimaan yang timbul sebagai akibat pelaksanaan anggaran. Sedangakan dalam upaya melaksanakan kewenangan kebendaharaan. Menteri Keuangan merupakan pengelola keuangan yang berfungsi sebagai kasir, pengawas keuangan, dan sekaligus sebagai manager keuangan.

3. Peraturan Pemerintah Republik Indonesia No. 20 Tahun 2004 Tentang Rencana Kerja Pemerintah

Undang-Undang No.17 Tahun 2003 tentang Keuangan negara mengamanatkan bahwa penyusunan Racangan Anggaran Belanja dan Pendapatan Negara (RAPBD) berpedoman pada Rencana Kerja Pemerintah (RKP). Sebagai rencana kerja, program dan kegiatan yang termuat dalam RKP sudah bersifat terukur dan dapat dilaksanakan karena sudah diperhitungkan ketersediaan anggaran. Artinya sebagai dokumen perencanaan, RKP tidak lagi memuat daftar panjang usulan kegiatan kementerian negara atau lembaga yang selama ini dianggap sebagai daftar keinginan yang belum tentu dapat dilaksanakan. Sebagai pedoman penyusunan RAPBD, RKP juga disusun dengan mengikuti pendekatan baru dalam penganggaran sebagaimana yang diamanatkan dalam Undang-Undang Keuangan Negara tersebut. Pendekatan beru tersebut mencapai 3 (tiga) hal : penerapan kerangka pengeluaran jangka menegah, penerapan penganggaran terpadu, dan penerapan penganggaran berbasis kinerja. 


\section{Peraturan Pemerintah No.90 Tahun 2010, Tentang Penyusunan Rencana Kerja Anggaran Kementrian Negara/Lembaga}

PP No.90 Tahun 2010 tentang penyusunan Rencana Kerja Anggaran kementrian negara atau lembaga, lebih menitik beratkan terhadap dinamika perkembangan proses penyusunan rancangan anggaran pendapatan dan belanja negara berbasis kinerja, maka dari itu perlu dilakukan penyempurnaan terhadap mekanisme penyusunan rencana kerja dan anggaran kementrian negara/lembaga sehingga menjadi lebih transparan dan akuntabel.

Dinamika yang terus berkembang dalam proses penyusunan rancangan anggaran pendapatan dan belanja negara berbasis kinerja, menuntut dilakukannya penyempurnaan landasan hukum penyusunan RKA$K / L$, khususnya agar dapat menampung tata cara penyusunan rencana kerja dan anggaran dari bagian anggaran bendahara umum negara yang anggarannyalebih besar dari pada anggaran bagian anggaran kementrian/lembaga. Sehubungan dengan hal tersebut perlu menggantu PP Nomor 21 Tahun 2004 tentang Penyusunan Rencana Kerja dan Anggaran Kementrian.

\subsection{Anggaran Belanja}

\subsubsection{Pengertian Anggaran Belanja}

Anggaran belanja merupakan penurunan manfaat ekonomis selama periode tertentu dalam bentuk arus keluar, arus defisit aset, atau terjadinya karena utang yang mengakibatkan berkurangnyaekuitas dana, selain yang berkaitan dengan distribusi kepada para peserta ekuitas pada pemerintah tersebut. Menurut abdul hakim (2008 : 322) pengertian belanja adalah penurunan aktiva dan atau kenaikan utang yang digunakan untuk berbagai kegiatan dalam satu periode akuntansi. Definisi belanja menurut Deddi Nordiawan dan Ayuningtyas Hertianti (2010 : 203) "Semua pengeluaran dari rekening kas umum negara/daerah yang mengurangi ekuitas dana lancar dalam periode tahun anggaran bersangkutan yang tidak akan diperoleh pembayarannya kembali oleh pemerintah".

Anggaran belanja merupakan pedoman pelaksanaan kegiatan pengeluaran keuangan negara/daerah yang disusun untuk kurun waktu tertentu. Dengan kata lain, anggaran belanja digunakan oleh instansi atau 
lembaga untuk mengetahui seberapa besar dana yang akan dikeluarkan oleh instansi tersebut gune memenuhi kebutuhan belanjanya. Kesimpulannya bahwa anggaran belanja merupakan penjabaran rencana pengeluaran/pembelanjaan keuangan yang dirinci untuk berbagai kegiatan dalam jangka tertentu. Digunakan sebagai taksiran serta penggunaannya diawasi, dikendalikan, dilaksanakan dan dipertanggungjawabkan.

\subsubsection{Fungsi Anggaran Belanja}

Anggaran belanja memiliki banyak fungsi seperti yang dikemukakan oleh Abdul Hakim (2008 : 113), yaitu :

1. Sebagai pedoman pemerintah dalam mengelola keuangan untuk satu periode dimasa yang akan datang.

2. Sebagai alat ukur untuk meningkatkan pelayanan publik dan kesejahteraan masyarakat.

3. Sebagai alat pengawasan bagi masyarakat terhadap kebijakan-kebijakan yang diambil oleh pemerintah.

4. Sebagai alat mengevaluasian kinerja pemerintah dalam periode tertentu.

\subsubsection{Klasifikasi Anggaran Belanja}

Klasifikasi belanja menurut organisasi disesuaikan dengan susunan organisasi pada masing-masing pemerintah daerah. Klasifikasi belanja menurut program dan kegiatan disesuaikan dengan urusan pemerintah yang menjadi wewenang daerah.

Menurut Indra Bastian (2007 : 154) anggaran belanja menurut kelompok dibagi menjadi dua :

1. Belanja Tidak langsung

Belanja tidak langsung merupakan belanja yang dianggarkan, tidak terkait secara langsung dengan pelaksanaan program dan kegiatan.

2. Belanja Langsung

Belanja langsung merupakan belanja yang dianggarkan, terkait secara langsung dengan pelaksanaan program dan kegiatan. 
Sedangkan secara umum anggaran belanja menurut Abdul Hakim (2008 : 69) dikelompokan menjadi lima kelompok, yaitu :

\section{Belanja Administrasi Umum}

Belanja Administrasi Umum adalah semua pengeluaran pemerintah daerah yang tidak berhubungan secara langsung dengan aktivitas pelayanan publik. Belanja administrasi umum terdiri dari :

a. Belanja Pegawai

Merupakan pengeluaran pemerintah daerah untuk orang atau personel yang didak berhubungan secara langsung dengan aktivitas atau biaaya tetap pegawai, seperti biaya gaji, biaya tunjangan, biaya perawatan, dan biaya pengembangan sumber daya manusia.

b. Belanja Barang

Merupakan pengeluaran pemerintah daerah untuk penyediaan barang dan jasa yang tidak berhubungan langsung dengan pelayanan publik. Belanja ini meliputi:

1. Biaya bahan habis pakai

2. Biaya jasa kantor

3. Biaya cetak dan penggandaan

4. Biaya langganan

5. Biaya pakai dinas

c. Belanja Perjalanan Dinas

Merupakan pengeluran pemerintah untuk biaya perjalanan pegawai atau dewan yang tidak berhubungan secara langsung dengan pelayanan publik, seperti:

1. Biaya perjalanan dinas

2. Biaya perjalanan pindah

3. Biaya pemulangan pegawai yang gugur, dipensiunkan, dan cuti besar

d. Belanja Pemeliharaan

Merupakan pengeluran pemerintah daerah untuk pemeliharaan barang daerah yang tidak berhubungan secara langsung dengan pelayanan publik, seperti:

1. Biaya pemeliharaan gedung dan kantor

2. Biaya pemeliharaan rumah dinas dan asrama

3. Biaya pemeliharaan meubelair

4. Biaya pemeliharaan perlengkapan kantor 
5. Biaya pemeliharaan peralatan kantor

6. Biaya pemeliharaan emplasment kantor

\section{Belanja Operasi dan Pemeliharaan Sarana dan Prasarana Publik}

Belanaja ini merupakan semua pengeluaran pemerintah daerah yang berhubungan dengan aktivitas pelayanan publik. Belanja ini meliputi belanja pegawai yang merupakan pengeluaran pemerintah daerah untuk orang atau personel yang berhubungan secara langsung dengan aktivitas atau baiay pegawai yang bersifat variabel. Belanja pegawai ini meliputi :
a. Honorarium
b. Upah lembur dan upah paket
c. Upah
d. Insentif

\section{Belanja Barang}

Merupakan pengeluran pemerintah daerah untuk penyediaan barang dan jasa yang berhubungan langsung dengan pelayanan publik, seperti biaya sewa dan biaya bahan percontohan.

\section{Belanja Perjalanan Dinas}

Merupakan pengeluaran pemerintah daerah untuk biaya perjalanan pegawai yang dengan pelayanan publik, sepeti biaya perjalan dinas dalam dan luar daerah.

\section{Belanja Pemeliharaan}

Merupakan pengeluran pemerintah daerah untuk pemeliharaan barang daerah yang berhubungan langsung dengan pelayanan publik. Belanja ini meliputi:

a. Belanaja pemeliharaan gedung dan umum

b. Biaya pemeliharaan jalan dan jembatan

C. Biaya pemeliharaan kendaraan

d. Biaya pemeliharaan perlengkapan operasional

e. Biaya pemeliharaan peralatan operasional

f. Biaya pemeliharaan emplasment

g. Biaya pemeliharaan mesin

h. Biaya pemeliharaan sungai dan kanal

i. Biaya pemeliharaan museum

j. Biaya pemeliharaan terminal

k. Biaya pemeliharaan taman 


\section{Belanja Transfer}

Belanja transfer merupakan pengalihan uang dari pemerintah daerah kepada pihak ketiga tanpa adanya harapan untuk mendapatkan pengembalian imbalan ataupun keuntungan dari pengalihan uang tersebut, seperti angsuran pinjaman, dana bantuan, dan dana cadangan.

\section{Belanja Tak Tersangka}

Belanaja tak tersangka adalah pengeluaran pemerintah yang dilakuakn oleh pemerintah daerah untuk membiayai kegiatan yang tak terduga dan kejadian luar biasa.

\section{Belanja Modal}

Belanja modal merupakan pengeluran pemerintah daerah yang manfaatnya melebihi satu tahun anggaran dan akan menambah aset atau kekayaan daerah tersebut dan selanjutnya akan menambah belanja yang bersifat rutin seperti biaya operasi dan pemeliharaan. Belanja ini meliputi:

a. Belanja Publik

Belanya yang manfaatnya dapat dinikmati oelh masyarakat umum.

b. Belanja Aparatur

Belanja yang manfaatnya tidak dapat dinikmati oleh masyrarakat, tetapi dirasakan secara langsung oleh aparatur. 


\section{BAB III}

\section{HASIL DAN PEMBAHASAN}

\subsection{Sejarah Dinas Pertanian}

Dinas Pertanian terbentuk dari 2 Dinas yaitu Dinas Perternakan dan Dinas Pertanian Tanaman Pangan. Dinas Peternakan Kota Bogor berdiri tahun 1930 dengan memiliki Rumah Potong Hewan (RPH) setelah itu berubah Dinas Kesehatan Hewan Kotamadya Bogor. Pada tahun 1960 berubah menjadi Dinas Peternakan. Sesuai dengan UU No 66 Tahun 1967 tentang Pokok-pokok Peternakan Kesehatan menjadi Dinas Peternakan. Perda No. 10 Tahun 1979 Kotamadya DT II Bogor tanggal 7 November 1979 tentang Susunan Organisasi Dinas Peternakan. Perda No. 5 tahun 1997 Kotamadya DT II Bogor tanggal 17 April 1997 tentang Organisasi dan Tata Kerja Dinas Peternakan Kotamadya DT II Bogor.

Pembentukan Dinas Pertanian Tanaman Pangan Kotamadya DT II Bogor sendiri dibentuk berdasarkan Perda Kotamadya DT II Bogor No. 11 tahun 1990 yaitu tentang Pembentukan Dinas Pertanian Tanaman Pangan Kotamadya DT II Bogor. Perda Kotamadya DT II Bogor No. 12 tahun 1990 tentang Susunan Organisasi dan Tata Kerja Dinas Pertanian Tanaman Pangan Kotamadya DT II Bogor. Perda Kotamadya DT II Bogor No. 6 tahun 1997 tentang Perubahan Susunan Organisasi dan Tata Kerja Dinas Pertanian Tanaman Pangan Kotamadya DT II Bogor.

Dinas Pertanian Kota Bogor dibentuk berdasarkan Peraturan Daerah Kota Bogor No. 19 tahun 2002 tentang Organisasi Perangkat Daerah Kota Bogor sebagai pengganti Perdam No. 10 Tahun 1999 Kotamadya DT II Bogor. Hal ini mengacu pada UU Nomor 22 Tahun 1999 bahwa bidang pertanian merupakan bidang pemerintah yang wajib dilaksanakan oleh daerah otonom Kota atau Kabupaten.

Dinas Pertanian merupakan gabungan 2 (dua) Dinas yaitu Dinas Pertanian Tanaman Pangan dan Dinas Peternakan. Ditetapkan dengan Perda Kota Bogor No. 19 Tahun 2000 tentang susunan Organisasi Perangkat Daerah Kota Bogor. Berdasarkan Perda No. 13 Tahun 2004 tentang SPOD (Susunan Organisasi Perangkat Daerah Dinas Pertanian Kota Bogor diganti nama menjadi Dinas Agribisnis Kota Bogor. 


\subsection{Visi dan Misi Dinas Pertanian}

Pertanian Perkotaan dapat diartikan sebagai pembudidayaan tanaman pangan, hortikultura, biofarmaka, ternak, ikan dan usaha pengolahan hasil serta pemasaran yang diarahkan untuk memenuhi selera/konsumen dengan memanfaatkan pekarangan atau lahan kosong. Pembangunan Pertanian sangat dibutuhkan untuk meningkatkan kemakmuran dan kesejahteraan masyarakat.

Sebagai suatu wilayah perkotaan di dalam pengembangan sektor pertanian, Dinas Pertanian memilih konsep "Pengembangan Agribisnis Perkotaan yang Berwawasan Lingkungan dan Berkelanjutan". Artinya bahwa dengan memanfaatkan sumberdaya yang tersedia secara efektif dan efisien, diharapkan dapat menjawab berbagai tantangan yang dihadapi, hal ini sesuai dengan Misi 1 Kota Bogor "Mengembangkan Perekonomian Masyarakat yang Bertumpu Pada Jasa Perdagangan".

Peran Sektor Pertanian sangat dibutuhkan untuk mewujudkan kesejahteraan petani, menciptakan kemandirian, memperluas kesempatan kerja, mendorong pertumbuhan ekonomi, menghasilkan devisa serta menciptakan ketahanan pangan. Sehubungan dengan hal tersebut salah satu peran Dinas Pertanian dengan produk yang dihasilkan dapat meningkatkan pendapat riil per kapita masyarakat dan diharapkan dapat mengurangi jumlah kemiskinan.

Untuk mewujudkan pembangunan pertanian tersebut Dinas Pertanian telah melaksanakan kegiatan-kegiatan yang meliputi peningkatan modal usaha produktif, peningkatan sarana dan prasarana pertanian, pengembangan sumber daya manusia, penguatan kelembagaan, dsb.

Sejalan dengan Visi dan Misi Kota Bogor tersebut, dan untuk mendukung tujuan dan sasarannya, maka disusunlah Visi Dinas Pertanian Kota Bogor "Mewujudkan agribisnis perkotaan untuk mendukung Bogor Kota Perdagangan". Berdasarkan Visi tersebut maka dilaksanakan tiga Misi untuk mencapai tujuan organisasi. Misi tersebut adalah :

1. Misi 1 : Meningkatkan produksi dan produktivitas melalui optimalisasi pemanfaatan sumber daya pertanian.

2. Misi 2 : Pengendalian hama/penyakit tanaman, ternak dan ikan untuk mendorong ketersediaan dan keamanan pangan secara kontinu dan berkelanjutan. 
3. Misi 3 : Peningkatan nilai tambah produk pertanian melalui pengembangan sistem dan usaha agribisnis

Visi dijabarkan dalam bentuk misi, selanjutnya visi dan misi dijabarkan kedalam bentuk yang lebih terarah dan operasional, berupa penetapan tujuan, sasaran dan strategis untuk mencapainya. Strategi meliputi kebijakan dan program.

Berdasarkan Visi dan Misi Kota Bogor tahun 2010 s/d 2014 disusunlah Arah Kebijakan Umum Kota Bogor untuk Dinas Pertanian. Dalam pelaksanaan keempat Misi Pemerintah Kota Bogor, Dinas Pertanian melaksanakan Misi I dengan tujuan :

1. Meningkatkan dan mempertahankan tingkat produksi dan meningkatkan produktivitas pertanian melalui optimalisasi pemanfatan sumber daya pertanian/perikanan.

2. Pemberdayaan usaha ekonomi masyarakat melalui peningkatan nilai tambah produk pertanian (pengolahan hasil)

3. Adanya pengembangan usaha pertanian perkotaan yang mengarah ke perdagangan agro dan jasa-jasa pertanian diantaranya melalui pengembangan agrowisata.

\subsection{Struktur Organisasi dan Uraian Tugas}

\subsubsection{Struktur Organisasi}

Berdasarkan Peraturan Daerah Kota Bogor Nomor 3 Tahun 2010 tentang Organisasi Perangkat Daerah. Dinas Pertanian Kota Bogor merupakan Perangkat Daerah sebagai unsur pelaksana teknis penyelenggaraan pemerintahan daerah yang mempunyai tugas pokok melaksanakan sebagian urusan di bidang pertanian. Dinas Pertanian Kota Bogor dipimpin oleh Kepala Dinas yang berada di bawah dan bertanggung jawab kepada Walikota Bogor.

Kepala Dinas Pertanian dalam melaksanakan tugasnya dibantu oleh 1 (satu) orang Sekretaris, 3 (tiga) orang Kepala Bidang, 3 (tiga) orang Kepala Sub Bagian dan 9 (sembilan) orang Kepala seksi serta 1 (satu) orang Kepala UPTD RPH. Selain itu ada kelompok jabatan fungsional yang berfungsi pembinaan dan pemberdayaan terhadap pelaku usaha bidang pertanian, perikanan dan peternakan.

Struktur Organisasi Dinas Pertanian Kota Bogor, terdiri dari : 
1. Kepala Dinas

2. Sekretariat, membawahi :
a. Sub Bagian Umum dan Kepegawaian;
b. Sub Bagian Keuangan;
c. Sub Bagian Perencanaan dan Pelaporan;

3. Bidang Tanaman Pangan dan Hortikultura, membawahi :
a. Seksi Pengolahan Hasil dan Pemasaran;
b. Seksi Sumber Daya;
c. Seksi Produksi;

4. Bidang Peternakan, membawahi :
a. Seksi Kesehatan Hewan;
b. Seksi Kesehatan Masyarakat Veteriner;
C. Seksi Produksi;

5. Bidang Perikanan, membawahi :
a. Seksi Pengolahan Dan Mutu Hasil;
b. Seksi Pemasaran dan Kelembagaan Usaha;
c. Seksi Budidaya dan Pengembangan;

6. UPTD (Unit Pelaksana Teknis Dinas) Rumah Potong Hewan Terpadu, membawahi Sub Bagian Tata Usaha 


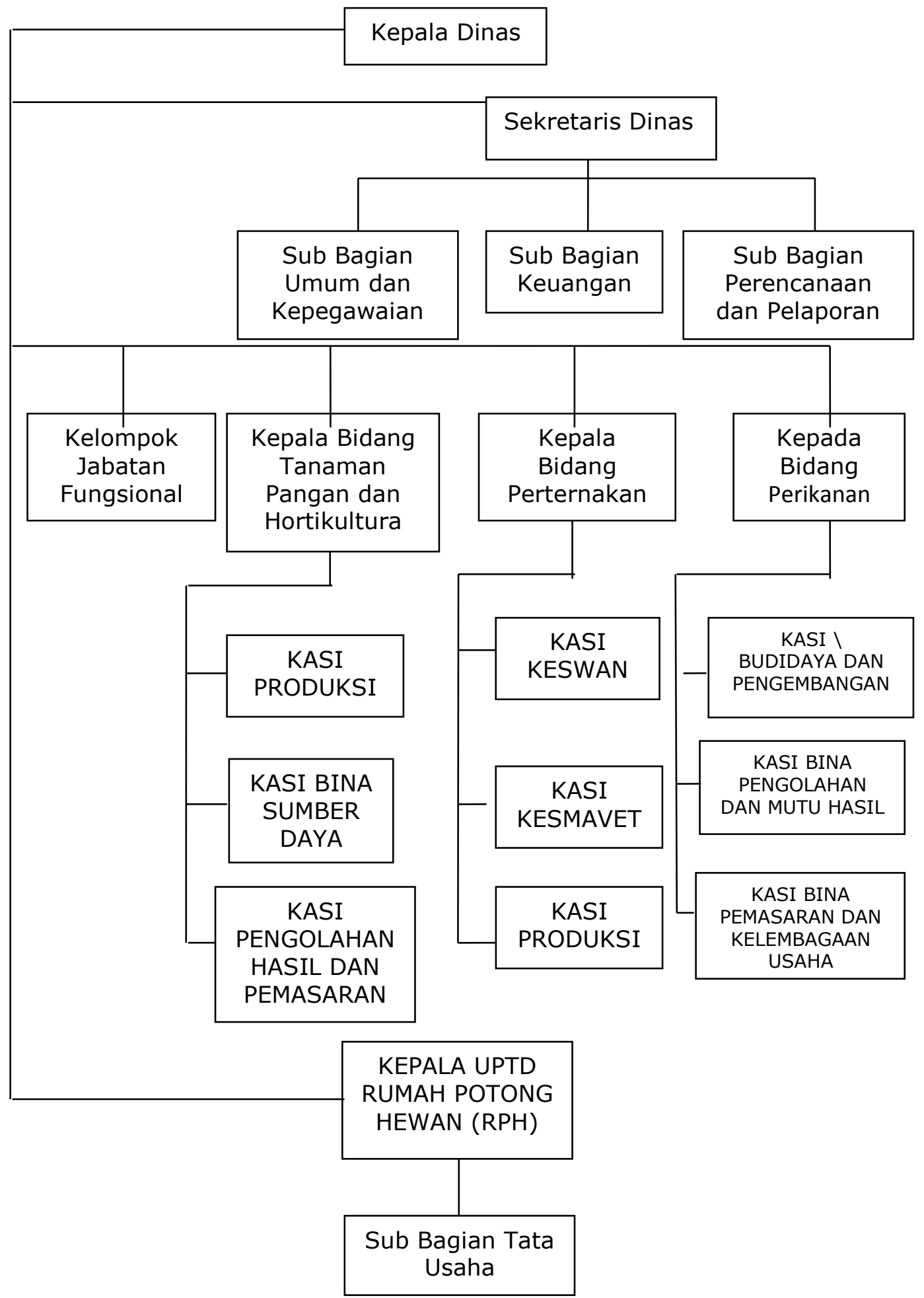

GAMBAR 3.1

Struktur Organisasi 


\subsubsection{Tugas Pokok dan Fungsi}

Dinas Pertanian Kota Bogor mempunyai tugas pokok melaksanakan sebagian urusan di bidang pertanian. Berdasarkan Peraturan Walikota Bogor Nomor 40 tahun 2008 tentang : Tugas Pokok, Fungsi, Tata Kerja dan Uraian Tugas Jabatan Struktural di Lingkungan Dinas Pertanian, tugas pokok Dinas Pertanian Kota Bogor adalah Melaksanakan kewenangan Otonomi Pemerintahan di Bidang Pertanian meliputi Bidang Tanaman Pangan dan Hortikultura, Bidang Perikanan, serta Bidang Peternakan yang menjadi urusan rumah tangga daerah.

Untuk melaksanakan tugas pokok sebagaimana dimaksud dalam Peraturan Walikota Nomor : 41 Tahun 2010, Dinas Pertanian mempunyai fungsi sebagai berikut :

1. Perumusan kebijakan teknis di bidang pertanian;

2. Penyelenggaraan urusan pemerintahan dan pelayanan umum di bidang pertanian;

3. Pembinaan dan pelaksanaan tugas di bidang pertanian;

4. Pelaksanaan tugas lain yang diberikan oleh walikota sesuai tugas dan fungsinya.

Sedangkan tugas jabatan struktural di dalam dinas pertanian terdapat pada daftar tabel dibawah ini :

\begin{tabular}{|c|c|c|}
\hline No. & Jabatan & Tugas dan Fungsi \\
\hline 1. & Kepala Dinas & $\begin{array}{l}\text { 1. Memimpin pelaksanaan tugas dinas pertanian } \\
\text { yang meliputi sekretariat, bidang tanaman pangan } \\
\text { dan holtikultura, bidang peternakan, bidang } \\
\text { perikanan dan UPTD rumah potong hewan terpadu } \\
\text { 2. Merumuskan rencana kerja Dinas Pertanian } \\
\text { 3. Mendistribusikan pekerjaan dan memberi petunjuk } \\
\text { pelaksanaan tugas kepada bawahan } \\
\text { 4. Mengarahkan RKA dan DPA serta mengendalikan } \\
\text { DPA } \\
\text { 5elaksanakan kerjasama dengan instansi, } \\
\text { lembaga, dan organisasi lainnya } \\
\text { Menyelenggarakan urusan pemerintahan dan } \\
\text { pelayanan umum bidang pertanian }\end{array}$ \\
\hline
\end{tabular}




\begin{tabular}{|c|c|c|c|}
\hline & & & $\begin{array}{l}\text { Melaporkan dan mempertanggungjawabkan } \\
\text { pelaksanaan tugas kepada atasan }\end{array}$ \\
\hline 2. & $\begin{array}{l}\text { Sekretaris } \\
\text { Dinas }\end{array}$ & 8. & 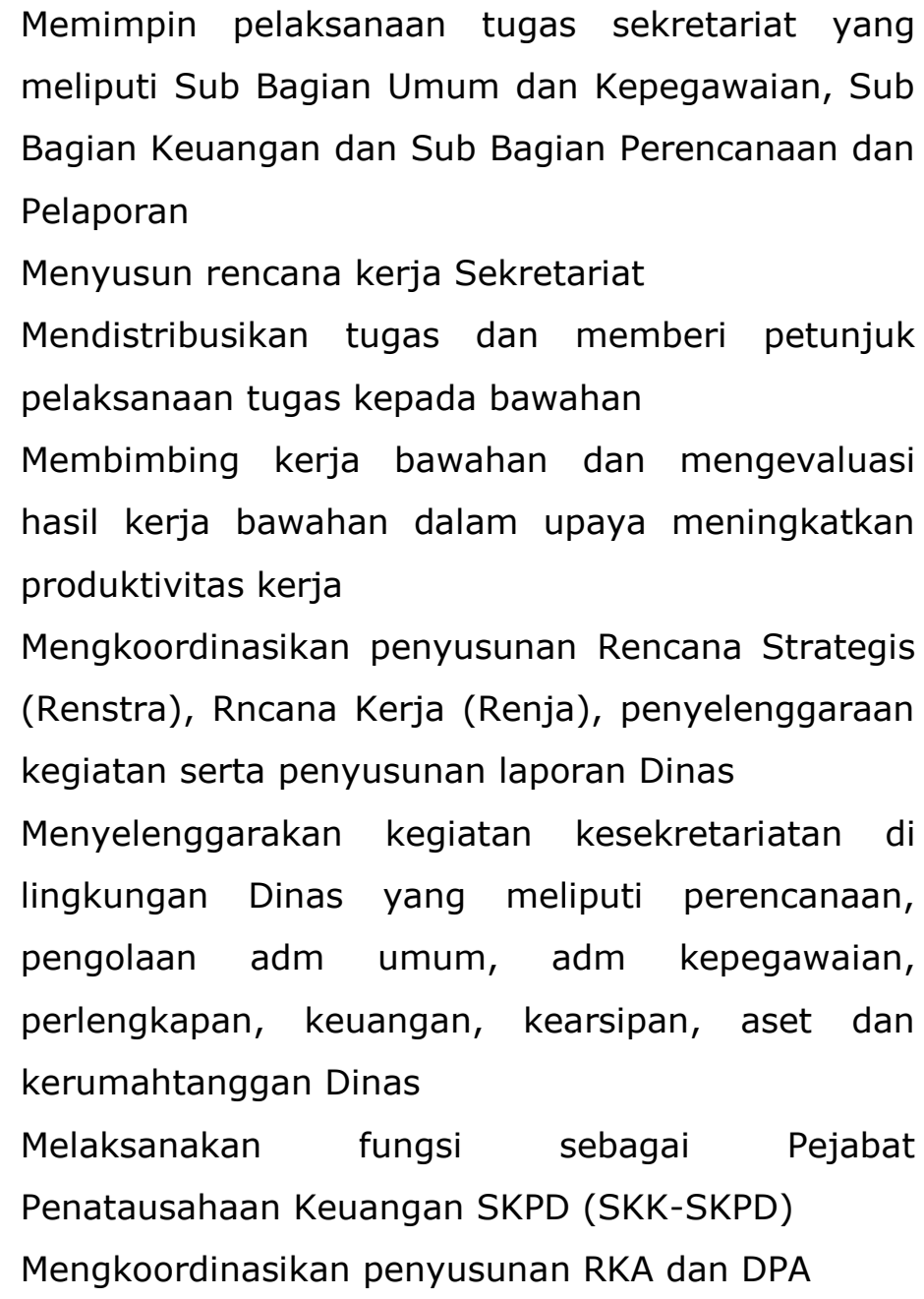 \\
\hline 3. & $\begin{array}{l}\text { Kepala Sub } \\
\text { Bagian Umum } \\
\text { dan } \\
\text { Kepegawaian }\end{array}$ & 1. & $\begin{array}{l}\text { Memimpin pelaksanaan tugas Sub Bagian Umum } \\
\text { dan Kepegawaian } \\
\text { Menyusun rencana kerja Sub Bagian Umum dan } \\
\text { Kepegawaian } \\
\text { Mendistribusikan tugas dan memberi petunjuk } \\
\text { pelaksanaan tugas kepada bawahan } \\
\text { Membimbing kerja bawahan dan mengevaluasi } \\
\text { hasil kerja bawahan dalam upaya meningkatkan } \\
\text { produktivitas kerja } \\
\text { Menyelenggarakan kegiatan pengelolaan surat } \\
\text { menyurat, kearsiapn, aset dan kerumahtanggan } \\
\text { Menyusun Rencana Kebutuhan Barang milik Daerah } \\
\text { (RKBMD), Rencana Kebutuhan Pemeliharaan }\end{array}$ \\
\hline
\end{tabular}




\begin{tabular}{|c|c|c|}
\hline & & $\begin{array}{l}\text { Barang Milik Daerah (RKPBMD) dan pengadaan } \\
\text { barang atau jasa lingkup dinas } \\
\text { 7. } \text { Melaksanakan pengolaan perlengkapan dan } \\
\text { pemeliharaan aset dinas } \\
\text { 8. Menyelenggarakan pengolaan adm kepegawaian } \\
\text { 9. Menyusun RKA dan DPA serta melaksanaan DPA }\end{array}$ \\
\hline 4. & $\begin{array}{l}\text { Kepala } \\
\text { Bagian } \\
\text { Keuangan }\end{array}$ & $\begin{array}{l}\text { Melaksanakan pelaksanaan tugas Sub Bagian } \\
\text { Keuangan } \\
\text { Memimpin pelaksanaan tugas Sub Bagian Umum } \\
\text { dan Kepegawaian } \\
\text { Menyusun rencana kerja Sub Bagian Keuangan } \\
\text { Mengelola gaji dan tugas pegawai } \\
\text { Mengkoordinir penyusunan RKA dan DPA lingkup } \\
\text { dinas } \\
\text { Memperoses dan menghimpun laporan keuangan } \\
\text { dan dana-dana yang bersumber dari bantuan } \\
\text { Pemerintah, Pemerintah Provinsi, Bantuan Luar } \\
\text { Negeri dan lainnya } \\
\text { Melaksanakan pengelolaan adm keuangan yang } \\
\text { meliputi penerimaan, pembukuan, penyimpanan, } \\
\text { pembayaran dan penyetoran pendapatan }\end{array}$ \\
\hline 5. & $\begin{array}{l}\text { Kepala Sub } \\
\text { Bagian } \\
\text { Perencanaan } \\
\text { dan Pelaporan }\end{array}$ & $\begin{array}{l}\text { Memimpin pelaksanaan tugas Sub Bagian Umum } \\
\text { dan Kepegawaian } \\
\text { Menyusun rencana kerja Sub Bagian Perencanaan } \\
\text { dan Pelaporan } \\
\text { Menyusun } \\
\text { Pertanggungjawaban (LKPJ), Laporan Akuntabilitas } \\
\text { Kinerja Instansi Pemerintah (LAKIP), Laporan } \\
\text { Penyelenggaraan Pemerintah Daerah (LPPD), dan } \\
\text { Laporan lainnya lingkup Dinas } \\
\text { Melaksanakan koordinasi dengan bidang dan sub } \\
\text { bidang dalam menyiapkan bahan Rencana } \\
\text { Pembangunan Jangka Menengah Daerah (RPJMD), } \\
\text { Menyusun Rencana Strategis (Renstra), dan } \\
\text { Rencana Kerja (Renja) dinas } \\
\text { Melaksanakan koordinasi dengan lintas program }\end{array}$ \\
\hline
\end{tabular}




\begin{tabular}{|c|c|c|c|}
\hline & & 9. & $\begin{array}{l}\text { dan lintas sektor dalam perencanaan kegiatan } \\
\text { Menghimpun data, informasi dan dokumentasi } \\
\text { sebagai bahan evaluasi dan pelaporan dinas } \\
\text { Melaksanakan pemutakhiran dan validasi data } \\
\text { Mengevaluasi dan monitpring hasil kegiatan } \\
\text { program pertanian } \\
\text { Menyusun RKA dan DPA serta melaksanakan DPA }\end{array}$ \\
\hline 6. & $\begin{array}{l}\text { Kepala Bidang } \\
\text { Tanaman } \\
\text { pangan dan } \\
\text { Holtikultura }\end{array}$ & 1. & $\begin{array}{l}\text { Merumuskan kebijakan, pedoman, petunjuk } \\
\text { pelaksaan atau petunjuk teknis di bidang tanaman } \\
\text { pangan dan holtikultura } \\
\text { Melaksanakan pembinaan dan pengarahan } \\
\text { pelaksanaan tugas bidang tanaman pangan dan } \\
\text { holtikultura } \\
\text { Menganalisi dan mengkaji penerapan } \\
\text { pengembangan teknologi tanaman pangan dang } \\
\text { holtikultura } \\
\text { Menyelengarakan pembinaan, bimbingan dan } \\
\text { praktek teknologi bidang tanaman dan holtikultura } \\
\text { Mengkoordinasikan RKA dan DPA }\end{array}$ \\
\hline 7. & $\begin{array}{l}\text { Kepala Seksi } \\
\text { Pengolahan } \\
\text { Hasil dan } \\
\text { Pemasaran }\end{array}$ & 1. & $\begin{array}{l}\text { Menyusun konsep kebijakan, pedoman, petunjuk } \\
\text { pelaksanaan atau petunjuk teknis seksi pengolahan } \\
\text { hasil dan pemasaran } \\
\text { Melaksanakan pengumpulan, pengolaha } \\
\text { analisa data dan perencanaan pengolahan hasil dan } \\
\text { pemasaran } \\
\text { Melaksanakan bimbingan teknis dan pembinaan } \\
\text { pengolahan hasil dan pemasaran } \\
\text { Melaksanakan promosi dan pameran pertanian } \\
\text { Melaksanakan monitoring harga dasar produk } \\
\text { pertanian } \\
\text { Melaksanakan bimbingan pasca panen dan } \\
\text { pengolahan hasil tanaman pangan dan holtikultura } \\
\text { Melaksanakan penerapan standarisasi pengolahan, } \\
\text { penyimpanan dan kemasan hasil tanaman pangan } \\
\text { dan holtikultura } \\
\text { Melaksanakan penyebarluasan dan pemantauan }\end{array}$ \\
\hline
\end{tabular}




\begin{tabular}{|c|c|c|c|}
\hline & & 10. & $\begin{array}{l}\text { penerapan teknologi panen, pasca panen dan } \\
\text { pengolahan hasil kota } \\
\text { Menyusun RKA dan DPA serta melaksankan DPA }\end{array}$ \\
\hline 8. & $\begin{array}{l}\text { Kepala Seksi } \\
\text { Sumber Daya }\end{array}$ & 8. & 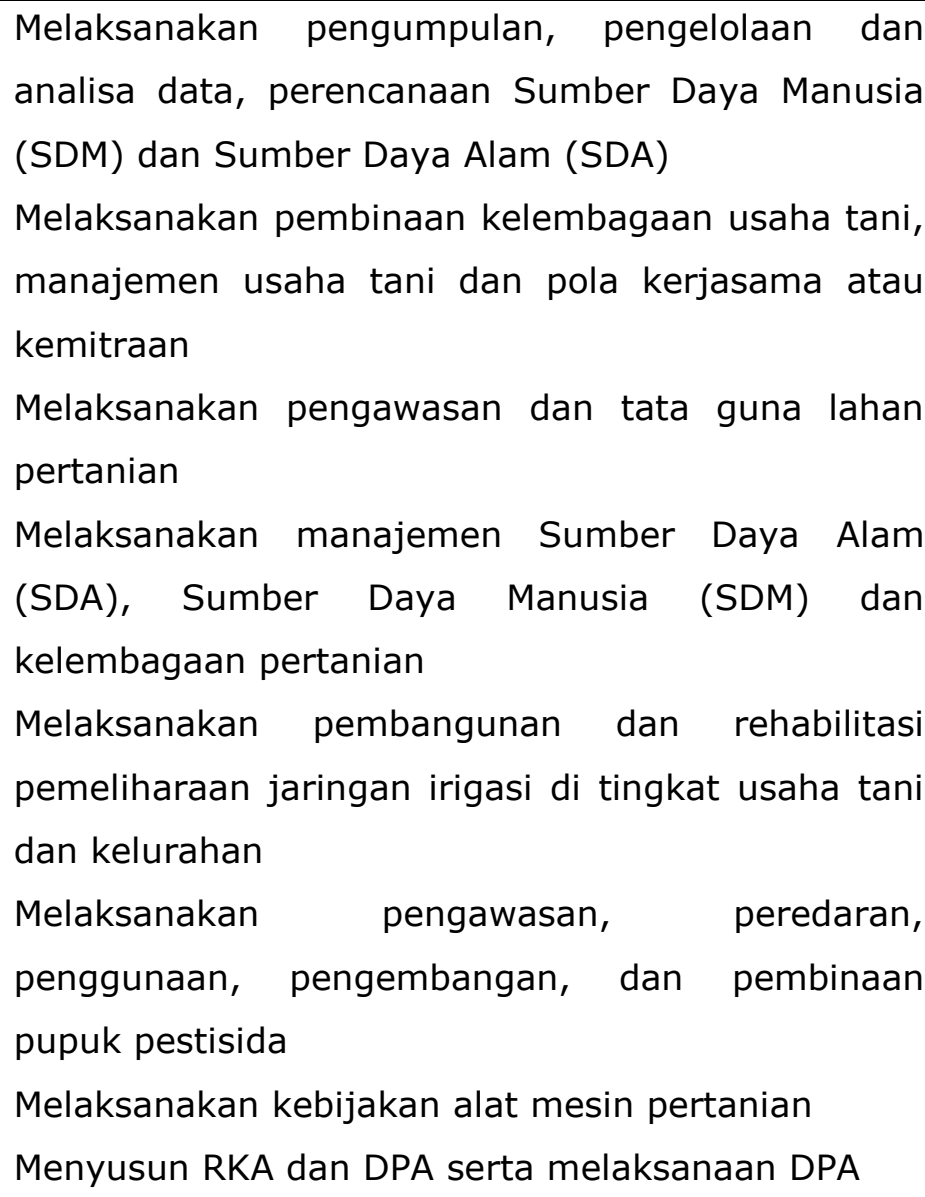 \\
\hline 9. & $\begin{array}{l}\text { Kepala } \\
\text { Produksi }\end{array}$ & 4. & $\begin{array}{l}\text { Melaksanakan penerapan teknologi budi daya dan } \\
\text { pembenihan atau pembibitan tanaman } \\
\text { Melaksanakan peraturan dan penerapan kawasan } \\
\text { pertanian terpadu wilayah kota } \\
\text { Melaksanakan hasil pemetasan produksi, } \\
\text { penetapan sentra komoditas dan sasaran areal } \\
\text { tanam } \\
\text { Melaksanakan hasil penetapan luas baku lahan } \\
\text { pertanian yang dapat diusahakan sesuai } \\
\text { kemampuan sumberdaya lahan yang ada pada } \\
\text { skala kota } \\
\text { Melaksanakan bimbingan penerapan teknologi } \\
\text { optimalisasi pengelolaan air untuk usaha tani } \\
\text { melaksanakan bimbingan penerapan teknologi }\end{array}$ \\
\hline
\end{tabular}




\begin{tabular}{|c|c|c|c|}
\hline & & 9. & $\begin{array}{l}\text { pembenihan dan pengawasan penangkaran benih } \\
\text { memberikan pelayanan rekomendasi sertifikasi } \\
\text { benih } \\
\text { melaksanakan pengamatan, identifikasi, pemetaan, } \\
\text { pengendalian dan analisis dampak kerugian } \\
\text { Organisme Penggangu Tanaman (OPT), } \\
\text { pemantauan dan pengamatan daerah yang diduga } \\
\text { sebagai sumber OPT } \\
\text { Menyusun RKA dan DPA serta melaksanaan DPA }\end{array}$ \\
\hline 10. & $\begin{array}{l}\text { Kepala Bidang } \\
\text { Perternakan }\end{array}$ & 1. & $\begin{array}{l}\text { Memimpin pelaksanakan tugas Bidang Perternakan } \\
\text { yang meliputi Seksi Kesehatan Hewan, Seksi } \\
\text { Kesehatan Masyarakat Veteriner serta Seksi } \\
\text { Produksik } \\
\text { Mengkoordinasikan rencana kerja Bidang } \\
\text { Perternakan } \\
\text { Merumuskan kebijakan, pedoman, petunjuk } \\
\text { pelaksanaan atau petuntuk teknis di bidang } \\
\text { perternakan } \\
\text { Mengkoordinasikan pelaksanaan penyuluhan, } \\
\text { bimbingan dan praktek lapangan teknologi bidang } \\
\text { perternakan } \\
\text { Merumuskan bahan pembinaan teknis kesehatan } \\
\text { hewan, pengawasan kesehatan masyarakat } \\
\text { veteriner dan produksi peternakan } \\
\text { Menganalisis, mengkaji dan menangani } \\
\text { permasalahan di bidang perternakan } \\
\text { Menyusun RKA dan DPA serta melaksanaan DPA }\end{array}$ \\
\hline 11. & $\begin{array}{l}\text { Kepala Seksi } \\
\text { Kesehatan } \\
\text { Hewan }\end{array}$ & 1. & $\begin{array}{l}\text { Melaksanakan pengendalian penyakit hewan dan } \\
\text { pemetaan penyakit hewan } \\
\text { Melaksanakan surveiles penyakit hewan menular } \\
\text { zoonosis } \\
\text { Memberikan pelayanan rekomendasi teknis } \\
\text { pemasukan dan pengeluaran hewan dan kedalam } \\
\text { wilayah Kota Bogor serta pengawasan lalu lintas } \\
\text { hewan } \\
\text { Memberikan pelayanan rekomendasi teknis }\end{array}$ \\
\hline
\end{tabular}




\begin{tabular}{|c|c|c|c|}
\hline & & 6. & $\begin{array}{l}\text { pembinaan dan pengawasan praktek dokter hewan } \\
\text { Memberikan pelayanan rekomendasi teknis } \\
\text { pembinaan, bimbingan teknis dan pengawasan } \\
\text { usaha vaksin atau obat prbiotik serta } \\
\text { peredarannya, poultry shop, pet sop, klinik hewan } \\
\text { dan Instansi Karantina Hewan Sementara (IKHS) } \\
\text { Melaksanakan pengenalan dan pengembangan } \\
\text { teknologi tepat guna peralatan dan pengobatan } \\
\text { penyakit hewan } \\
\text { Menyusun RKA dan DPA serta melaksanaan DPA }\end{array}$ \\
\hline 12. & $\begin{array}{l}\text { Kepala Seksi } \\
\text { Kesehatan } \\
\text { Masyarakat } \\
\text { Veteriner }\end{array}$ & $\begin{array}{l}7 . \\
8 .\end{array}$ & $\begin{array}{l}\text { Melaksanakan pembinaan dan bimbingan usaha } \\
\text { rumah potong hewan dan rumah potong unggas } \\
\text { Melaksanakan pemantauan pelaksanaan } \\
\text { pemotongan hewan dan unggas serta penyakit } \\
\text { zoonosis } \\
\text { Melaksanakan pengawasan dan pengujian terhadap } \\
\text { mutu pangan dan bahan pangan asal hewan } \\
\text { Melaksanakan pembinaan teknis pengawasan } \\
\text { kesejahteraan hewan } \\
\text { Melaksanakan pengelolaan laboraturium kesehatan } \\
\text { masyarakat veteriner } \\
\text { Melaksanakan pemantauan, } \\
\text { pengolahan data dan analisa pasar hasil produksi } \\
\text { bahan pangan asal hewan dan pasca panen } \\
\text { Melaksanakan pelayanan rekomendasi izin } \\
\text { pemasukan dan pengeluaran Pangan Asal Hewan } \\
\text { (PAH) dan Bahan Pangan Asal Hewan (BPAH) dari } \\
\text { kedalam wilayah Kota Bogor } \\
\text { Menyusun RKA dan DPA serta melaksanaan DPA }\end{array}$ \\
\hline 13. & $\begin{array}{ll}\text { Kepala } & \text { Seksi } \\
\text { Produksi } & \end{array}$ & 1. & $\begin{array}{l}\text { Melaksanakan pengawasan dan pembinaan teknis } \\
\text { budi daya dan produksi usaha perternakan } \\
\text { Melaksanakan pembinaan dan bimbingan teknis } \\
\text { pemasaran hasil produksi usaha perternakan } \\
\text { Melaksanakan pembinaan dan bimbingan teknis } \\
\text { serta pengawasan Inseminasi Buatan (BI) dan } \\
\text { Pemeriksaan Kebuntingan (PKB) }\end{array}$ \\
\hline
\end{tabular}




\begin{tabular}{|c|c|c|}
\hline & & $\begin{array}{l}\text { 4. Melaksanakan penyusunan dan pengolahan data } \\
\text { usaha produksi perternakan } \\
\text { 5. Melaksanakan penyusunan dan penyebaran } \\
\text { informasi data statistika dan teknologi produksi } \\
\text { perternakan } \\
\text { 6. Melaksanakan pengawasan dan pengujian mutu } \\
\text { pakan pada usaha produksi perternakan } \\
\text { 7. Melaksanakan pelayanan rekomendasi izin usaha } \\
\text { perternakan } \\
\text { 8. Melaksanakan bimbingan teknis pengelolaan limbah } \\
\text { usaha perternakan } \\
\text { Menyusun RKA dan DPA serta melaksanaan DPA }\end{array}$ \\
\hline 14. & $\begin{array}{l}\text { Kepala Bidang } \\
\text { Perikanan }\end{array}$ & $\begin{array}{l}\text { 1. Merumuskan kebijakan, pedoman, bimbingan } \\
\text { teknis dan paket teknologi bidang perikanan } \\
\text { 2. Mengkoordinasikan tata pemanfaatan air dan tata } \\
\text { pembudidayaan ikan } \\
\text { 3. Mengkoordinasikan pengawasan, peredaran dan } \\
\text { penggunaan pada sarana prasarana bidang } \\
\text { perikanan } \\
\text { 4. Merumuskan kajian teknologi bidang perikanan } \\
\text { 5. Merumuskan sistem informasi benih ikan } \\
\text { 6. Merumuskan Cara Budidaya Ikan yang Baik (CBIB) } \\
\text { dan Cara Pembenihan Ikan yang Baik (CPIB) } \\
\text { 7. Menyusun RKA dan DPA serta melaksanaan DPA }\end{array}$ \\
\hline 15. & $\begin{array}{l}\text { Kepala Seksi } \\
\text { Pengelolaan } \\
\text { dam Mutu Hasil }\end{array}$ & $\begin{array}{l}\text { 1. Melaksanakan bimbingan teknis dan memfasilitasi } \\
\text { 2. Mengolahan dan mutu hasil perikanan } \\
\text { bagi Unit Pengolahan Ikan (UPI) } \\
\text { 3. Melaksanakan uji mutu produk pengolahan ikan } \\
\text { 4. Melaksanakan pengkajian dan penerapan paket } \\
\text { teknologi pengolah dan mutu hasil perikanan } \\
\text { 5. Melaksanakan pengkajian dan penerapan paket } \\
\text { teknologi pengolah dan mutu hasil perikanan } \\
\text { 6. Melaksanakan pengawasan Penerapan Manajemen } \\
\text { Mutu Terpadu (PMMT) di UPI, alat transportasi dab } \\
\text { unit penyimpanan hasil perikanan }\end{array}$ \\
\hline
\end{tabular}




\begin{tabular}{|c|c|c|}
\hline & & 7. Mel \\
\hline 16. & $\begin{array}{l}\text { Kepala Seksi } \\
\text { Pemasaran dan } \\
\text { Kelembagaan } \\
\text { Usaha }\end{array}$ & $\begin{array}{l}\text { 1. Memfasilitasi sumber-sumber pembiayaan untuk } \\
\text { meningkatkan pemasaran dan kelembagaan usaha } \\
\text { 2. } \\
\text { 2. Melaksanananan pengamatan, pemantauan, } \\
\text { pengendalian dan membrikan bimbingan } \\
\text { pemasaran perikanan } \\
\text { 3. Melaksanakan promosi dan pameran } \\
\text { 4. Melaksanakan bimbingan teknis dan memfasilitasi } \\
\text { pemasaran dan kelembagaan usaha } \\
\text { 5. Melaksankan pembinaan pasar ikan secara higienis } \\
\text { 6. Mengembangkan jejaring pasar, baik lokal, regional } \\
\text { maupun Internasional }\end{array}$ \\
\hline 17. & $\begin{array}{l}\text { Kepala Seksi } \\
\text { Budi Daya dan } \\
\text { Pengembangan }\end{array}$ & $\begin{array}{l}\text { 1. Melaksanakan pelaksanaan tugas lingkup UPTD } \\
\text { 2. Mumah Potong Hewan Terpadu } \\
\text { Terpadu } \\
\text { 3. Menyusun konsep kebijakan, pedoman, petunjuk } \\
\text { pelaksanaan atau petunjuk teknis oada UPTD RPH } \\
\text { 4. Melaksanakan koordinasi pelayanan, pengendalian } \\
\text { dan pengawasan kegiatan serta penggunaan } \\
\text { sarana dan prasarana RPH } \\
\text { 5. Melaksanakan pengelolaan dan pemeliharaan RPH } \\
\text { 6. Melaksanakan pemeriksaan kesehatan daging, } \\
\text { hewan potong di UPTD RPH } \\
\text { 7. Melaksanakan pemungutan retribusi penggunaan } \\
\text { sarana dan prasarana RPH } \\
\text { 8. Menyusun RKA dan DPA serta melaksanaan DPA }\end{array}$ \\
\hline 18. & $\begin{array}{l}\text { Sub Bagian } \\
\text { Tata Usaha }\end{array}$ & $\begin{array}{l}\text { Menyusun konsep naskah dinas yang berkaitan } \\
\text { dengan Sub Bagian Keuangan } \\
\text { Melaksanakan koordinasi dalam pelaksanaan } \\
\text { kegiatan pelayananankan umum } \\
\text { Menyelenggarakan ketatausahaan yang meliputi } \\
\text { adm umum, adm keuangan, adm kepegawaian, }\end{array}$ \\
\hline
\end{tabular}




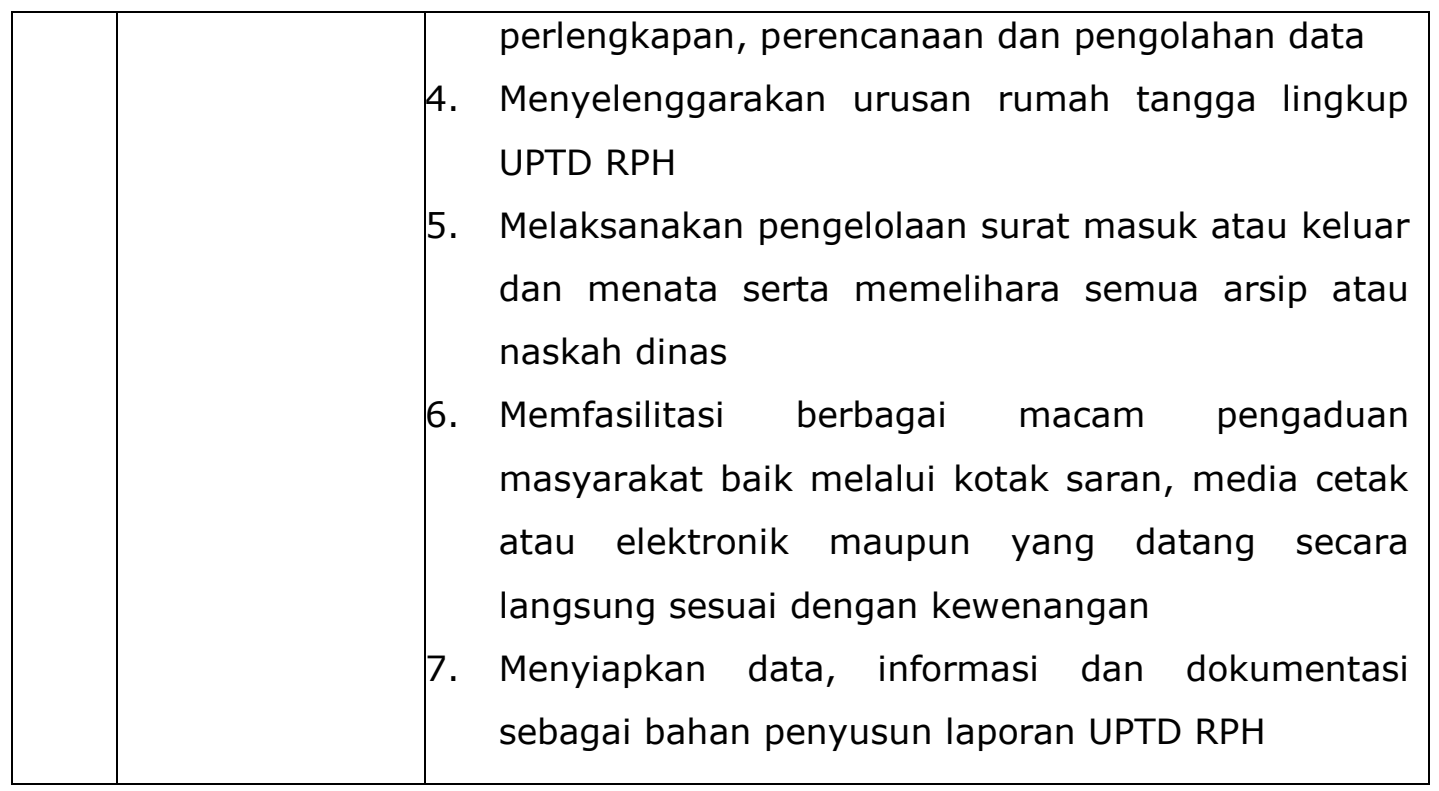

Tabel 3.2

Tupoksi Jabatan

\subsection{Sumber Daya Manusia}

Pengelolaan Kepegawaian meliputi administrasi kepegawaian dan administrasi umum. Administrasi kepegawaian meliputi penyusunan Daftar Urut Kepangkatan (DUK), nominatif pegawai, menyiapkan DP-3 dan Surat Keterangan Untuk Mendapatkan Pembayaran Tunjangan Keluarga (SKUM PTK), usulan kenaikan pangkat, gaji berkala, serta usulan pembuatan Karis/Karsu, Karpeg, Askes dan administrasi kepegawaiaan lainnya. Sedangkan administrasi umum meliputi pengelolaan surat menyurat, kearsipan, aset dan kerumahtanggaan termasuk perlengkapan dan pemeliharaan aset dinas.

Untuk menunjang kelancaran pelaksanaan tugas, Dinas Pertanian Kota Bogor memiliki 91 orang personil terdiri dari 65 orang Pegawai Negeri Sipil Kota Bogor (termasuk 2 orang penyuluh). Selain itu, Dinas Pertanian Kota Bogor mendapat bantuan 2 (dua) orang pegawai dari propinsi sebagai petugas pengawas benih dan petugas pengamat hama penyakit dan 3 orang Tenaga Kerja Kontrak (termasuk personil UPTD - RPH), 8 orang Tenaga Sukwan dan Tenaga Harian Lepas (THL) 13 orang. Apabila dilihat dari segi kuantitas jumlah personil tersebut belum memadai, dan dari segi kualitas kemampuan dan kompetensi para personil yang ada masih perlu ditingkatkan melalui pendidikan dan pelatihan sesuai dengan kompetensi dan secara berjenjang dan berkesinambungan. 
Keadaan pegawai pada Dinas Pertanian Kota Bogor Tahun 2014 seperti tercantum yang dibawah ini :

\begin{tabular}{|c|l|c|c|c|}
\hline NO & \multicolumn{1}{|c|}{$\begin{array}{c}\text { STATUS } \\
\text { KEPEGAWAIAN }\end{array}$} & $\begin{array}{c}\text { PADA DINAS } \\
\text { (ORANG) }\end{array}$ & $\begin{array}{c}\text { PADA UPTD RPH } \\
\text { (ORANG) }\end{array}$ & $\begin{array}{c}\text { JUMLAH } \\
\text { (ORANG) }\end{array}$ \\
\hline 1 & PNS-Golongan IV & 8 & - & 8 \\
\hline 2 & PNS-Golongan III & 24 & 6 & 30 \\
\hline 3 & PNS-Golongan II & 17 & 4 & 6 \\
\hline 4 & PNS-Golongan I & 2 & 3 & 3 \\
\hline 5 & Tenaga Kontrak & - & - & 13 \\
\hline 6 & THL & 13 & 19 & 91 \\
\hline & JUMLAH & 72 &
\end{tabular}

Tabel 3.3

Keadaan Pegawai Dinas Pertanian Kota Bogor Tahun 2015

\subsection{Sarana dan Prasarana}

Dinas Pertanian Kota Bogor terletak di Jalan Cipaku No.5 Bogor, memiliki sarana dan prasarana sebagai berikut :

1. Terminal Agribisnis (TA) Ikan Hias di Kelurahan Rancamaya, Kecamatan Bogor Selatan.

2. UPTD Rumah Potong Hewan Terpadu di Kelurahan Bubulak, Kecamtan Bogor Barat.

3. Holding Ground Ikan Hias di Kelurahan Cipaku, Kecamatan Bogor Selatan.

4. Laboratorium Kultur Jaringan di Kelurahan Cipaku, Kecamatan Bogor Selatan.

5. Pos Kesehatan Hewan dan Pos Inseminasi Buatan (IB) di Kelurahan Cipaku, Kecamatan Bogor Selatan.

6. Depo Pemasaran Ikan Hias di jalan Binamarga, Kelurahan Baranangsiang, Kecamatan Bogor Timur.

7. Balai Benih Ikan Mini di Kelurahan Kencana, Kecamatan Tanah Sareal.

8. Rintisan pembibitan tanaman dan ternak kecil/kesayangan di Kelurahan Cipaku, Kecamatan Bogor Selatan.

9. Sub Terminal Agribisnis (STA) Rancamaya.

10. RPH Bubulak. 
11. Depo Ikan Hias Binamarga.

12. Pusat Pemasaran Hasil Perikanan (Fishmart) di jalan padjajaran bogor.

13. Balai Benih Ikan Kencana.

\subsection{Uraian Singkat Kegiatan Magang}

Di hari pertama penulis diberikan pengarahan dan pengenalan mengenai ruang lingkup kantor Dinas Pertanian (Distani). Penulis di tempatkan di bagian keuangan. Di hari pertama itu juga penulis melakukan kerja seperti input pajak yang telah dibayar ke dalam komputer dan merekap daftar gaji pegawai.

Dalam minggu berikutnya penulis diberikan pekerjaan yaitu, melanjutkan mencatat surat rekapitulasi pajak, menginput daftar gaji tahun 2014, mencatat daftar tunjangan tambahan pegawai, dan menyusun berkas Surat Pertanggung Jawaban (SPJ) bulan Januari dan Februari.

Di minggu berikutnya atau minggu ke-3 penulis diberi pekerjaan membuat daftar kegiatan tugas jabatan, merekap daftar gaji Gol 1 sampai dengan Gol 4, mengisi format Simpeg bagian keuangan, menginput data Surat Perintah Membayar (SPM), merekapitulasi Surat Permintaan Pembayaran (SPP), dan mengecek kelengkapan SPJ bulan Februari.

Minggu berikutnya penulis diberikan kegiatan merekap kartu kendali kegiatan bulan Februari, menginput pajak disetiap kegiatan, memberi No.Reg pada SPJ bulan Januari sampai dengan Februari, membetulkan No.Reg pada bulan Februari, dan juga membetulkan No.Reg pada bulan Januari.

Di awal bulan Mei penulis diberi kegiatan menagih kelengkapan SPJ bulan April di setiap kegiatan, mengecek kelengkapan SPJ bulan April yang sudah siap untuk diinput, input data pinjaman setiap pegawai, ikut menghadiri rapat di Bank Pasar tentang pinjaman pegawai, menagih kelengkapan SPJ di bulan April yang masih ada kekurangan, dan memberi No.Reg di bulan April.

Minggu terakhir kegiatan magang penulis diberikan tugas menyamakan jumlah pajak, merekap kartu kendali kegiatan bulan April, menginput pajak setiap kegiatan yang belum sempat diinput, mengembalikan SPJ bulan April ke setiap bagian yang belum lengkap, membuat daftar tunjangan pegawai, dan ikut mengambil uang kegiatan di Bank Jabar. 


\subsection{Perbandingan Antara Teori dan Praktek}

\subsubsection{Proses Penyusunan Anggaran Belanja pada Dinas Pertanian}

Berdasarkan nota kesepakatan antara Pemerintah Daerah dengan DPRD, TAPD menyiapkan rancangan surat edaran walikota tentang pedoman penyusunan Rencanana Kerja dan Anggaran Satuan Kerja Perangkat Daerah (RKA-SKPD) sebagai acuan dalam menyusun RKA-SKPD. Berdasarkan pedoman penyusunan APBD yang ditetapkan dengan Surat Edaran Walikota yang didalamnnya memuat Kebijakan Umum APBD (KUA) dan Prioritas Plafon Anggaran Sementara (PPAS) yang telah ditetapkan, Pemerintah Daerah memulai Pejabat Pengola Keuangan Daerah (PPKD) menyusun rancangan APBD. Rancangan APBD yang disusun, merupakan kumpulan dari usulanusulan yang telah dususun dan diajukan oleh satuan kerja perangkat daerah (SKPD) dan pejabat pengelola keuangan daerah dalam lingkungan pemerintah daerah yang dituangkan dalam masing-masing Rencana Kerja Anggaran Satuan Kerja Perangkat Daerah (RKA-SKPD). Pembuatan Rencana Kerja Anggaran pada SKDP dimulai pada bulan Juni-Juli dan Selesai pada bulan November-Desember atau disebut juga Dokumen Pelaksanaan Anggaran.

\section{Pelaksanaan dan Pihak Terkait Dalam Penyusunan RKA-SKPD}

a. Walikota

Walikota mengotorisasi Rangcangan Surat Edaran (SE) Walikota menjadi SE walikota tentang Pedoman Penyusunan RKA-SKPD, paling lambat awal bulan Agustus tahun anggaran belanja

b. Sekda

1) Sekda menyetujui rancangan awal SE Walikota tentang Pedoman Penyusunan RKA-SKPD serta meneruskan kepada Walikota

2) Sekda mengkoordinasi penyebaran SE Walikota tentang pedoman Penyusunan RKA-SKPD kepada SKPD-SKPD

c. Tim Anggaran Pemerintah Daerah (TAPD)

1) TAPD rancangan awal SE Walikota Bogor tentang Pedoman Penyusunan RKA-SKPD kepada Sekda.

2) TAPD membahas RKA-SKPD untuk melihat kesesuaian RKASKPD dengan RKPD, Renja SKPD, KU APBD, PPAS, prakiraan maju yang telah disetujui pada RKA-SKPD tahun anggaran 
sebelumnya, dan dokumen perencanaan lainnya. Hasil pembahasan menjadi bahan lampiran Rancangan Peraturan Daerah APBD.

3) Dalam hasil pembahasan RKA-SKPD yang telah dilakukan TAPD terdapat ketidaksesuaian, maka RKA-SKPD dikembalikan kepada SKPD yang bersangkutan, untuk perbaikan atau penyempurnaan.

4) TAPD menyerahkan seluruh dokumen RKA-SKPD hasil penyempurnanaan RKA-SKPD.

d. Kepala SKPD (Satuan Kerja Perangkat Daerah)

1) SKPD menerima SE Walikota tentang Pedoman Penyusunan RKA-SKPD

2) Kepada SKPD selaku pengguna anggaran menyusun RKASKPD berdasarkan Kebijakan Umum APBD serta pedoman penyusunan RKA-SKPD. Penyusunannya mencangkup :

1. SKPD menyusunan rincian Anggaran Pendapatan untuk menghasilkan RKA-SKPD 1 . Form RKA-SKPD 1 disiapkan hanya oleh SKPD pemungut pendapatan.

2. SKPD menyusun Rincian Anggaran Belanja Tidak Langsung untuk menghasilkan RKA-SKPD.

3. SKPD menyusun rincian Anggaran Belanja Langsung masing-masing kegiatan untuk menghasilkan RKASKPD untuk kemudian digabung dalam rekapitulasi Rincian Anggaran Belanja Langsung untuk menghasilkan RKA-SKPD.

4. SKPD mengkompilasi dokumen RKA-SKPD diata menjadi RKA-SKPD.

5. Kepala SKPD melakukan penyempurnaan RKA-SKPD (kalau terjadi ketidaksesuaian RKA-SKPD dengan dokumen perencanaan lainnya), menyampaikan kepada TAPD.

e. Pejabat Pengeola Keuangan Daerah (PPKD)

1) PPKD menerima seluruh dokumen RKA-SKPD dari SKPD untuk proses penyusunan Rancangan Peraturan Daerah APBD dan Rancangan Peraturan Daerah APBD dan Rancangan Peraturan Walikota Penjabaran APBD. 
2) Dokumen RKA-SKPD yang telah diterima oleh PPKD dan Dokumen RKA-PPKD yang telah disusun, disampaikan kepada TAPD untuk dibahas lebih lanjut.

3) Menerima kembali dokumen SKPD dan hasil pembahasan TAPD dan perbaikan SKPD

\section{Dokumen dan data yang diperlukan untuk penyusunan RKA- SKPD}

Sebagai langkah awal penyusunan rancangan peraturan daerah APBD. Tim Anggaran Pemerintah Daerah (TAPD) meyiapkan rancangan awal Surat Edaran (SE) Walikota Bogor tentang pedoman penyusunan RKA-SKPD. Penyusunan pedoman tersebut mengacu pada nota kesepakatan KUA dan PPAS yang telah disepakati serta dokumen-dokumen pendukung lain seperti analisis standar belanja. Secara rinci, dalam rangka penyusunan RKA-SKPD, substansi rancangan surat edaran Walikota tentang pedoman penyusunan RKA-SKPD mencangkup :

a. Prioritas pembangunan daerah dan pedoman atau kegiatan yang terkait.

b. Alokasi plafon anggaran sementara untuk setiap program atau kegiatan SKPD.

c. Batas waktu penyampaian RKA-SKPD.

d. Dokumen sebagai lampiran surat edaran meliputi Kebijakan Umum APBD (KUA), Prioritas Plafon Anggaran Sementara PPAS, analisis standar belanja, dan standar satuan harga

Selain itu diperlukan daftar program dan kegiatan yang akan digunakan pada setiap SKPD (non urusan) dan daftar program dan kegiatan per urusan per bidang yang akan digunakan SKPD dalam penyusunan RKA untuk menjamin keseragaman dan menghindari adanya duplikasi kegiatan yang sama baik dalam nama maupun substansi isinya. Surat Edaran Walikota tentang pedoman penyusunan anggaran RKA-SKPD disampaikan kepada skpd paling lambat bulan Angustus tahun anggaran berjalan. Selain SE Walikota juga diperlukan kode dan klasifikasi urusan pemerintah daerah dan organisasi, kode dan klasifikasi belanja dan struktur dan kode rekening, dalam hal ini dinas pertanian memiliko kode yaitu 2011. 
Dokumen KAU yang dilampirkan Surat Edaran Walikota memuat antara lain:

1. Kondisi ekonomi makro daerah,

2. Asumsi penyusunan APBD,

3. Kebijakan pendapatan daerah,

4. Kebijakan belanja daerah,

5. Kebijakan pembiyaan daerah,

6. Strategi pencapaian.

Sedangkan PPAS yang dilampirkan oleh SE Walikota memuat antara lain:

1. Penentuan skala prioritas pembangunan daerah,

2. Penentuan skala prioritas program masing-masing urusan,

3. Penyusunan plafon anggaran sementara untuk masing-masing program atau kegiatan.

\section{Langkah-langkah teknis penyusunan anggaran RKA-SKPD}

Langkah 1 : Persiapan pedoman penyusunan RKA-SKPD.

a. TAPD menyerahkan rancangan awal SE Walikota Bogor tentang pedoman penyusunan RKA-SKPD kepada Sekda.

b. Sekda menyetujui rancangan awal SE Walikota tentang pedoman Penyusunan RKA-SKPD dan meneruskannya kepada Walikota.

c. Walikota mengotorisasi rancangan SE Walikota menjadi SE Walikota tentang pedoman penyusunan RKA-SKPD paling lambat awal bulan agustus tahun anggaran berjalan.

d. Sekda mengkoordinasi penyebaran SE Walikota tentang pedoman penyusunan RKA-SKPD kepada SKPD-SKPD.

Langkah 2 : Penyusunan RKA-SKPD serta RKA lanjutan Pemerintah Kota Bogor.

a. SKPD menerima SE Walikota tentang pedoman penyusunan RKASKPD.

b. SKPD mulai menyusun dokumen rencana kerja dan anggaran satuan kerja perangkat daerah (RKA-SKPD) masing-masing, berdasarkan SE Walikota tentang pedoman penyusunan RKA-SKPD.

1) Dokumen RKA-SKPD memuat rencana pendapatan, rencana belanja untuk masing-masing program dan kegiatan untuk tahun 
yang direncanakan, yang dirinci sampai dengan obyek pendapatan, belanja serta perkiraan maju untuk tahun berikutnya terdiri dari :

a) RKA- SKPD (ringkasan anggaran pendapatan, belanja dan pembiayaan satuan kerja perangkat daerah)

b) RKA-SKPD 1 (rincian anggaran pendapatan satuan kerja perangkat daerah)

c) RKA-SKPD 2.1 (rincian anggaran tidak langsung satuan kerja perangkat daerah)

d) RKA-SKPD 2.2 (rekapitulasi rincian anggaran belanja langsung menurut program dan kegiatan satuan kerja pemerintah)

e) RKA-SKPD 2.2.1 ( rincian anggaran balanja langsung menurut program dan per kegiatan satuan kerja perangkat daerah)

2) Dokumen RKA-SKPD disusun oleh masing-masing SKPD berpedoman pada surat edaran walikota perihal pedoman penyusunan RKA-SKPD.

3) Dokumen SKA-SKPD yang disusun sesuai dengan urutannya.

c. Setelah kepala SKPD menyusun laporan akhir realisasi pelaksanaan kegiatan fisik dan nonfisik maupun keuangan kemudian menyusun RKA lanjutan yang berisi:

1) Saldo DPA tahun awal penganggaran.

2) Keterangan penyebab tidak dapat diselesaikan sampai dengan akhir tahin anggaran berjalan.

3) Jumlah belanja yang telah direalisasi di tahun pertama.

4) Jumlah anggaran yang dilanjutkan di tahun kedua.

d. Penyampaian seluruh dokumen RKA-SKPD dan RKA-L kepada PPKD dalam rangka penyusunan rancangan peraturan daerah tentang APBD dan rancangan peraturan walikota tentang penjabaran APBD.

e. Form RKA-SKPD dan RKA-L yang telah disusun oleh masing-masing SKPD ditandatangani oleh kepala SKPD dan selanjutnya disampaikan kepada PPKD (Pejabat Pengelolaan Keuangan Daerah).

g. Dokumen RKA-SKPD dan RKA-L yang telah diterima oleh PPKD disampaikan kepada TAPD untuk dibahas lebih lanjut. 
Langkah 3 : Pembahasan RKA dengan Tim anggaran pemerintah daerah

a. RKA-SKPD, RKA-L yang telah disusun oleh masing-masing organisasi satuan kerja perangkat daerah disampaikan kepada PPKD. RKA-SKPD dan RKA-L kemudian disampaikan kepada Tim Anggaran Pemerintah Daerah (TAPD) untuk dibahas. Pembahasan tersebut dilakukan untuk menelaah :

1. Kesesuaian RKA-SKPD, RKA-L ddengan KUA, PPAS, prakiraan maju pada RKA-SKPD dan RKA-PPKD tahun berjalan yang disetujui tahun lalu, dan dokumen perencanaan lainnya.

2. Kesesuaian rencana anggaran dengan standar analisis belanja, standar satuan harga.

3. Kelengkapan instrumen pengukuran kinerja yang meliputi capaian kinerja, indikator kinerja, kelompok sasaran kegiatan, dan standar pelayanan minimal.

4. Proyeksi prakiraan maju untuk tahun anggaran beerikutnya.

5. Sinkronisasi program dan kegiatan antar RKA-SKPD.

Langkah rinci pembahasan yang dilakukan TAPD diatur dalam surat keputusan Walikota tentang penunjukan/pengangkatan TAPD beserta uraian tugas nya.

b. Penyempurnaan RKA-SKPD dan RKA-L

Apabila hasil pembahasan RKA-SKPD dan RKA-L oleh TAPD terdapat ketidak sessuaian atau kesalahan, maka RKA-SKPD dan RKA-L dikembalikan kepada SKPD yang bersangkutan, untuk penyempurnaan RKA-SKPD dilakukan oleh staf SKPD yang ditunjukan untuk menyusun RKA-SKPD.

c. Kepala SKPD setelah melakukan penyempurnaan RKA-SKPD, RKA-L menyampaikannya kembali kepada TAPD.

d. TAPD menyerahkan seluruh dokumen RKA-SKPD, SKA-L dan RKAPPKD hasil penyempurnaan kepada PPKD.

e. Seluruh dokumen RKA-SKPD dan RKA-L yang akan disampaikan kepada PPKD tersebut sudah ditandatangani oleh kepala SKPD dan mendapatkan paraf dan pengesahan dari TAPD dalam form RKASKPD dan RKA-L yang tersedia. 
Tidak

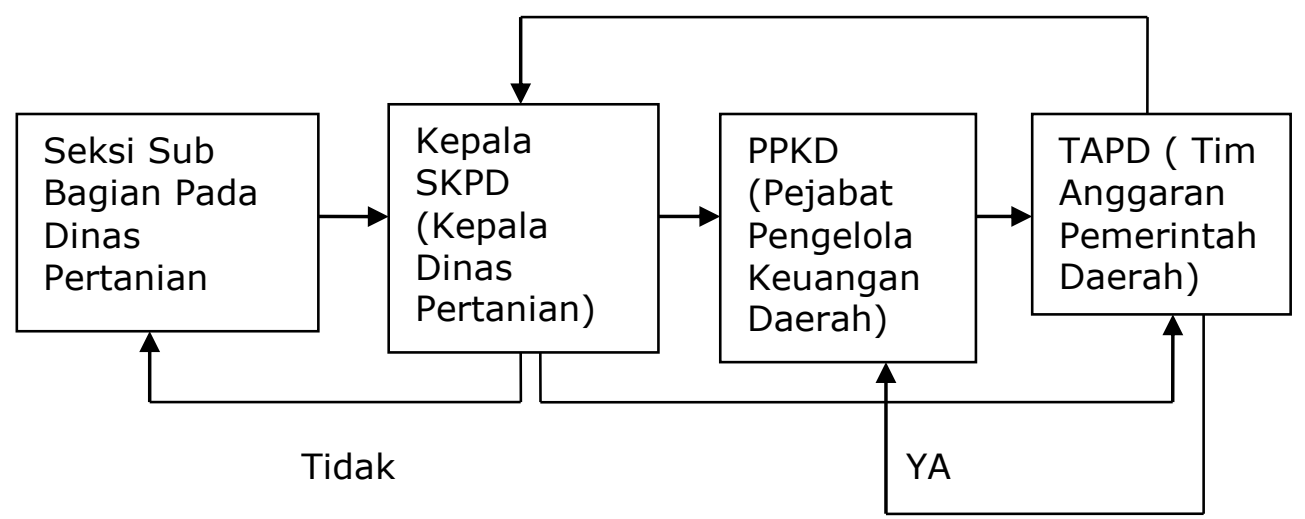

YA

Gambar 3.2

Siklus Penyusunan Anggaran Belanja

Keterangan :

1. Pada bulan Juni-Juli Sub Bagian pada Dinas Pertanian melakukan penyusunan anggaran belanja dan lalu diserahkan kepada kepala Dinas.

2. Kepada SKPD atau Kepala Dinas Pertanian menyerahkan RKA-SKPD kepada PPKD.

3. RKA-SKPD yang diterima oleh PPKD lalu diserahkan kepada TAPD untuk dibahas lebih lanjut.

4. Apabila terdapat ketidaksesuain atau kesalahan maka RKA-SKPD dikembalikan kepada Kepala Dinas Pertanian untuk diperbaiki.

5. Kepala Dinas Pertanian mengembalikan RKA-SKPD kepada Sub Bagian untuk diperbaiki dan disempurnakan.

6. Setelah disempurnakan Sub Bagian menyerahkan lagi kepada Kepala Dinas untuk selanjutnya kembali diberikan kepada TAPD.

7. TAPD menyerahkan seluruh dokumen RKA-SKPD dan RKA-L hasil penyempurnaan kepada PPKD dan sudah ditandatangani oleh Kepala Dinas Pertanian dan mendapatkan paraf pengesahan dari TAPD.

8. Proses penyusunan anggaran belanja selesai pada bulan NovemberDesember atau disebut juga DPA (Dokumen Pelaksanaan Anggaran). 


\subsubsection{Dasar Dalam Penyusunan Anggaran Belanja Pada Dinas Pertanian}

Rencana Kerja Dinas Pertanian Kota Bogor Tahun 2014 yang digunakan sebagai acuan di dalam pelaksanaan kegiatan di bidang pertanian dan untuk mengetahui anggaran belanja di setiap kegiatan yang dilaksanakan. Rencana Kerja Tahun 2014 merupakan penjabaran dari Rencana Strategis (Rentra) Dinas Pertanian Kota Bogor. Rencana Kerja Rencana Kerja Kementerian Negara atau Lembaga (Renja-KL) memuat kebijakan, program dan kegiatan pembangunan baik yang dilaksanakan langsung oleh pemerintah maupun yang ditempuh dengan mendorong partisipasi masyarakat.

Proses penyusunan rencana kerja Dinas Pertanian berpedoman pada Peraturan Daerah Kota Bogor Nomor 5 Tahun 2010 tentang Rencana Pembangunan Jangka Menengah Daerah (RPJMD) Kota Bogor Tahun 2010 2014 dan memperhatikan hasil kinerja pembangunan yang dicapai pada tahun sebelumnya, fenomena yang ada, isu isu strategis yang akan dihadapi pada tahun pelaksanaan Rencana Kerja serta sinergitas antar sektor dan antar wilayah, serta memperhatikan azaskoordinasi dengan seluruh OPD serta berbagai pihak, baik politisi, teknokrat, tokoh masyarakat maupun para pemangku kepentinganlainnya dalam sector pertanian yang termuat dalam Musyawarah Rencana Pembangunan (Musrenbang) baik di tingkat kecamatan maupun kota.

RPJMD tersebut bagi Dinas Pertanian akan dijadikan pedoman penyusunan Renstra Dinas Pertanian. Setiap tahunnya, RPJMD akan dijabarkan dalam Rencana Kerja Pemerintah Daerah (RKPD) Pemerintah Kota Bogor yang selanjutnya dijadikan pedoman bagi penyusunan Rancangan Anggaran Pendapatan dan Belanja Daerah (RAPBD) Kota Bogor, sedangkan bagi Dinas Pertanian, RKPD ini akan dijadikan acuan untuk menyusun Rencana Kerja (Renja) Dinas Pertanian. Berdasarkan Renja Dinas Pertanian disusun Rencana Kerja dan Anggaran (RKA). Setelah RAPBD disahkan menjadi APBD, maka disusun rincian APBD dalam bentuk DPA SKPD. Skema Keterkaitan Antara Renja SKPD, Renstra dan Dokumen Perencanaan lainnya dapat dilihat dalam Gambar di bawah ini. 


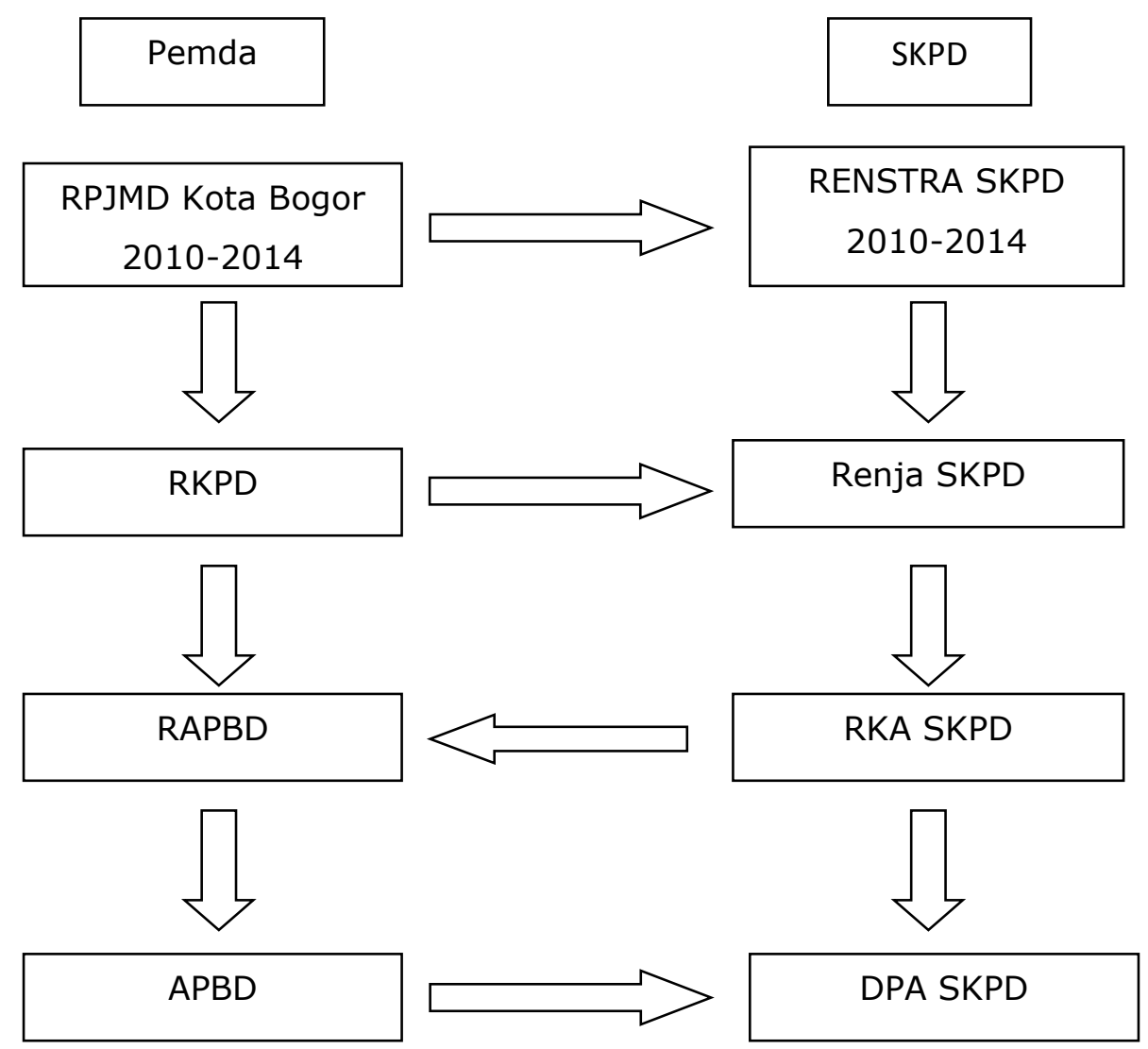

Gambar 3.3

Keterkaitan antara Renja SKPD, Renstra dan Dokumen Perencanaan Lainnya.

Dengan tersusunnya Rencana Kerja - SKPD Dinas Pertanian Kota Bogor Tahun 2014, maka diharapkan Penyusunan Laporan Akuntabiliitas Kinerja Instansi Pemerintah (LAKIP) yang akan dibuat setelah tahun anggaran dapat lebih obyektif karena rencana tingkat capaian (target) kegitan telah ditetapkan pada awal tahun kerja. Selanjutnya dengan adanya Rencana Kerja - SKPD ini dapat memacu kinerja seluruh pegawai Dinas Pertanian Kota Bogor dan dapat bertanggung jawab untuk merealisasikan rencana tingkat capaian (target).

Hal-hal penting yang perlu diperhatikan dalam rangka pelaksanaan sebagai berikut :

1. Perlu memenuhi Standar Operasional Prosedur (SOP) yang telah ditetapkan dan disesuaikan dengan Petunjuk Teknis yang diberikan oleh instansi teknis diatasnya.

2. Perlu adanya penyusunan skala prioritas dalam pelaksanaan kegiatan. Hal tersebut juga diperlukan apabila ketersediaan 
anggaran terbatas, sehingga kegiatan yang menjadi prioritas dan dibutuhkan oleh masyarakat lebih diutamakan.

3. Perlu memperhatikan azas efesiensi dan efektiftifitas dalam menggunakan anggaran yang ada.

\subsubsection{Kesesuaian Anggaran Belanja Dengan Ketentuan yang Melandasinya}

Pelaksanaan anggaran belanja digunakan untuk berbagai aktivitas yang dilaksanakan untuk mencapai sasaran yang dituju. Pembebanan biaya berperan dalam mengukur berbagai sumberdaya yang dipakai dalam melaksanakan aktivitas tersebut. Dengan adanya perhitungan biaya maka Dinas Pertanian dapat melakukan pengeluaran atau pembelanjaan yang telah direncanakan oleh pejabat yang berwenang selaku pengguna anggaran belanja sehingga realisasi anggaran belanja dapat tercapai.

Dinas Pertanian wajib menyusun rencana atas anggaran belanja yang disesuaikan dengan kebutuhan program atau kegiatan yang akan dilaksanakan, kemudian dituangkan dalam rencana tahunan. Anggaran belanja yang telah ditetapkan semula dapat mengalami perubahan dalam realisasinya, perubahan tersebut disesuaikan dengan kebutuhan pengeluaran atau pembelanjaan program atau kegiatan yang bersangkutan. Jika perubahan anggaran dilakukan dapat mengakibatkan penambahan atau pengurangan anggaran termasuk didalamnya pergeseran atau perubahan rincian anggaran. Di dalam Dinas Pertanian Anggaran Belanja Dibagi menjadi 2 (dua) klasifikasi yaitu anggaran belanja langsung dan anggaran belanja tidak langsung.

1. Belanja Tidak Langsung

Berdasarkan Peraturan Daerah Kota Bogor Nomor 7 tahun 2013, Peraturan Nomor 1 Tahun 2014, dan Peraturan Menteri Dalam Negeri Nomor 27 Tahun 2013 tentang pedoman penyusunan anggaran pendapatan dan Belanja Daerah. Bahwa penggaran belanja tidak langsung yang dianggarkan dalam SKPD meliputi :

a. Belanja pegawai dalam bentuk gaji dan tunjangan serta penghasilan yang diberikan kepada Pegawai Negeri Sipil (PNS) yang ditetapkan sesuai dengan ketentuan perundang-undangan. 
b. Khusus SKPD Sekretariat DPRD selain bentuk gaji dan tunjangan serta penghasilan lainnya sebagaimana dimaksud pada angka (1), dianggarkan Belanja Penunjang Operasional Pimpinan DPRD sesuai dengan Peraturan Pemerintah Nomor 21 Tahun 2007 dan Peraturan Menteri Dalam Negeri Nomor 21 Tahun 2007.

\section{Anggaran Belanja Langsung}

Belanja langsung dapat dinamakan belanja aktivitas atau belanja kegiatan. Jenis belanja yang dianggarkan dalam program atau kegiatan dapat berupa belanja pegawai, belanja barang dan jasa serta belanja modal sesuai dengan program atau kegiatan yang diusulkan oleh masing-masing SKPD. Karakteristik belanja langsung adalah sebagai berikut:

a. Dianggarkan untuk setiap program atau kegiatan yang diusulkan oleh SKPD.

b. Jumlah anggaran belanja langsung suatu program atau kegiatan dapat diukur atau dibandingkan secara langsung dengan output program atau kegiatan yang bersangkutan.

c. Variabilitas jumlah jenis belanja langsung oleh target kinerja atau tingkat pencapaian yang diharapkan dari program atau kegiatan yang bersangkutan.

Dasar Hukum Anggaran Belanja Langsung sama dengan belanja tidak langsung. Pembebanan anggaran belanja langsung kedalam anggaran SKPD lebih lanjut dibebankan kedalam jenis belanja, dengan rincian sebagai berikut:

a. Anggaran belanja langsung untuk kegiatan output-nya berupa bukan barang modal (bukan aset tetap) atau kegiatan non investasi dalam struktur anggaran SKPD dibebankan dalam jenis belanja :
1. Belanja Pegawai
2. Belanja Barang dan jasa

b. Anggaran belanja langsung untuk kegiatan yang outputnya berupa barang modal (aset tetap) atau kegiatan investasi dalam struktur anggaran SKPD dibebankan dalam jenis belanja modal. Dalam penganggaran belanja modal harus termasuk biaya-biaya tambahan yang berkaitandan dibutuhkan agar aset tetap yang 
dihasilkan dari belanja modal tersebut siap digunakan atau dimanfaatkan untuk kepentingan Pemerintah Daerah.

Pada bagian ini penulis akan menampilkan laporan anggaran belanja dan realisasi untuk tahun 2014 :

\begin{tabular}{|c|c|c|c|c|}
\hline No & Uraian & Anggaran (Rp) & Realisasi (Rp) & $\begin{array}{c}\text { Selisih Lebih atau } \\
\text { (Kurang) Anggaran } \\
\text { (Rp) }\end{array}$ \\
\hline 1. & $\begin{array}{c}\text { Belanja } \\
\text { Pegawai } \\
\text { (Belanja Tidak } \\
\text { Langsung) }\end{array}$ & 4.123 .363 .235 & 4.037 .649 .683 & 85.713 .552$. \\
\hline 2. & $\begin{array}{c}\text { Belanja } \\
\text { Pegawai } \\
\text { (Belanja } \\
\text { Langsung) }\end{array}$ & 1.377 .853 .000 & 1.285 .353 .000 & 92.500 .000 \\
\hline 3. & $\begin{array}{c}\text { Belanja } \\
\text { Barang dan } \\
\text { Jasa }\end{array}$ & 5.054 .160 .000 & 4.610 .129 .402 & 444.030 .598 \\
\hline 4. & $\begin{array}{c}\text { Belanja Modal } \\
\text { Jumlah }\end{array}$ & 14.449 .461 .235 & 13.432 .704 .945 & 1.016 .756 .290 \\
\hline
\end{tabular}

Tabel 3.4

Anggaran dan Realisasi Belanja

Dinas Pertanian

Anggaran belanja yang tercantum pada laporan anggaran Tahun Anggaran (TA) 2014 pada Dinas Pertanian adalah sebesar 14.449.461.235 dengan realisasi 13.432.704.945, sisa anggaran belanja 1.016.756.290 terdapat anggaran belanja tidak langsung dan belanja langsung (belanja modal, dan belanja barang dan jasa.

Anggaran Belanja Tidak Langsung yang tercantum pada laporan Anggaran Tahun (TA) 2014 pada Dinas Pertanian adalah sebesar 4.123.363.235 dengan realisasi sebesar 4.037.649.680, sisa dari anggaran belanja tidak langsung tersebut sebesar 85.713.552. Anggaran Belanja Tidak Langsung tersebut dibagi menjadi 13 yaitu : 


\begin{tabular}{|c|c|c|c|c|}
\hline No. & Uraian & Anggaran (Rp) & Realisasi (Rp) & $\begin{array}{c}\text { Realisasi } \\
\text { diatas } \\
\text { (dibawah } \\
\text { anggaran } \\
(\mathrm{Rp}) \text { ) }\end{array}$ \\
\hline 1. & $\begin{array}{l}\text { Gaji Pokok PNS atau Uang } \\
\text { representasi }\end{array}$ & 2.448 .011 .729 & 2.419.276.901 & 28.734 .828 \\
\hline 2. & Tunjangan Keluarga & 251.046 .688 & 249.291 .526 & 1.755 .162 \\
\hline 3. & Tunjangan jabatan & 182.195 .000 & 177.875 .000 & 4.320 .000 \\
\hline 4. & Tunjangan Fungsional & 26.370 .000 & 27.390 .000 & $(1.020 .000)$ \\
\hline 5. & Tunjangan Umum & 103.870 .000 & 102.150 .000 & 1.720 .000 \\
\hline 6. & Tunjangan Beras & 172.867 .500 & 166.028 .800 & 6.838 .700 \\
\hline 7. & $\begin{array}{l}\text { Tunjangan PPh/Tunjangan } \\
\text { Khusus }\end{array}$ & 42.978 .544 & 42.640 .997 & 337.547 \\
\hline 8. & Pembulatan Gaji & 46.274 & 46.459 & $(185)$ \\
\hline 9. & $\begin{array}{l}\text { Tamb. Penghasilan } \\
\text { Berdasarkan Beban Kerja }\end{array}$ & 58.200 .000 & 61.200 .000 & $(3.000 .000)$ \\
\hline 10. & $\begin{array}{l}\text { Tamb. Penghasilan } \\
\text { Berdasarkan Kondisi Kerja }\end{array}$ & 10.800 .000 & 10.800 .000 & - \\
\hline 11. & $\begin{array}{l}\text { Tamb.Penghasilan Berdasarkan } \\
\text { Kelangkaan Profesi }\end{array}$ & 18.000 .000 & 18.000 .000 & - \\
\hline 12. & $\begin{array}{l}\text { Tamb. Penghasilan } \\
\text { Berdasarkan Prestasi Kerja } \\
\text { (Objektif Lain) }\end{array}$ & 782.000 .000 & 762.950 .000 & 19.050 .000 \\
\hline 13. & Insentif Retribusi Daerah & 26.977 .500 & - & 26.977 .500 \\
\hline \multicolumn{2}{|r|}{ Jumlah } & 4.123 .363 .235 & 4.037 .649 .680 & 85.713 .552 \\
\hline
\end{tabular}

Tabel 3.5

Anggaran Belanja Tidak Langsung

Dinas Pertanian Kota Bogor

Anggaran Belanja Tidak Langsung yang tercantum pada laporan Anggaran Tahun (TA) 2014 dengan realisasi Rp.10.326.098.000. Anggaran Belanja Tidak Langsung tersebut dibagi menjadi Belanja pegawai (Belanja 
Langsung), belanja barang dan jasa, belanja modal (Belanja Modal Peralatan dan Mesin, Belanja Modal Gedung dan Bangunan).

Belanja Pegawai (Belanja langsung) memiliki anggaran sebesar Rp.1.377.853.000 dengan realisasi sebesar Rp.1.285.353.000, sisa dari anggaran belanja pegawai tersebut sebesar Rp. 92.500.000. Belanja pegawai tersebut dibagi menjadi beberapa pengeluaran yaitu :

\begin{tabular}{|c|c|c|c|c|}
\hline No. & Uraian & Anggaran (Rp) & Realisasi (Rp) & $\begin{array}{l}\text { Realisasi } \\
\text { Diatas } \\
\text { (dibawah } \\
\text { anggaran } \\
\text { (Rp) }\end{array}$ \\
\hline 1. & $\begin{array}{l}\text { Honorarium Pelaks. } \\
\text { Kegiatan - PNS }\end{array}$ & 543.005 .000 & 491.855 .000 & 51.150 .000 \\
\hline 2. & $\begin{array}{l}\text { Honorarium Tim } \\
\text { Pengadaan Barang dan } \\
\text { Jasa }\end{array}$ & 78.900 .000 & 62.450 .000 & 16.450 .000 \\
\hline 3. & $\begin{array}{l}\text { Honorarium Pegawai } \\
\text { Tidak Tetap }\end{array}$ & 25.948 .000 & 25.948 .000 & - \\
\hline 4. & $\begin{array}{l}\text { Honorarium Non } \\
\text { PNS/Pelaks. Kegiatan }\end{array}$ & 717.100 .000 & 692.200 .000 & 24.900 .000 \\
\hline 5. & Upah Kerja & 5.400 .000 & 5.400 .000 & - \\
\hline 6. & $\begin{array}{l}\text { Uang untuk diberikan } \\
\text { kpd masy. }\end{array}$ & 7.500 .000 & 7.500 .000 & - \\
\hline & Jumlah & 1.377 .853 .000 & 1.285 .353 .000 & 92.500 .000 \\
\hline
\end{tabular}

Tabel 3.6

Anggaran Pegawai pada Dinas Pertanian

Sedangkan belanja barang dan jasa memiliki anggaran sebesar Rp.5.054.160.000 dengan realisasi sebesar Rp.4.610.129.402, sisa dari anggaran belanja dan modal tersebut Rp. 444.030.598. Anggaran belanja modal dan jasa tersebut dibagi menjadi beberapa pengeluaran seperti salah satunya belanja perlengkapan dan peralatan dinas pertanian. 
Sedangkan belanja modal memiliki anggaran sebesar Rp.3.894.085.000 dengan realisasi sebesar Rp.3.499.572.860, sisa dari belanja modal adalah sebesar Rp.394.512.140. Anggaran belanja modal sendiri di dinas pertanian dibagi menjadi 2 yaitu belanja modal peralatan dan mesin, belanja modal gedung dan bangunan. Belanja peralatan dan mesin memiliki anggaran sebesar Rp.1.894.085.000 dengan realisasi sebesar Rp.1.551.489.815, sisa dari belanja modal peralatan dan mesin sebesar Rp.342.595.185. Sedangkan belanja modal gedung dan bangunan memiliki anggaran sebesar Rp.2.000.000.000 dengan realisasi sebesar Rp.1.948.083.045, sisa dari belanja modal gedung dan bangunan sebesar Rp.51.916.955.

Ruang lingkup anggaran belanja sebagai dana utama dari anggaran yang disusun oleh Dinas Pertanian (Distani) berlandaskan Peraturan Daerah Kota Bogor Nomor 7 Tahun 2013 tentang Anggaran Pendapatan dan Belanja Daerah Tahun Anggaran 2014, yang landasan operasionanya ditetapkan berdasarkan Peraturan Walikota Bogor Nomor 36 Tahun 2013 tentang penjabaran Anggaran Pendapatan dan Belanja Daerah Tahun Anggaran Pendapatan dan Belanja Daerah Tahun Anggaran 2014. Bahwa berdasarkan Peraturan Gubernur Jawa Barat Nomor 1 Tahun 2014 tentang Penjabaran Anggaran Pendapatan dan Belanja Daerah Tahun Anggaran 2014, Pemerintah Kota Bogor memperoleh Bantuan Keuangan Provinsi Jawa Barat yang sudah jelas peruntukannya. Bahwa sesuai dengan peraturan Menteri Dalam Negeri Nomor 27 Tahun 2013 tentang Pedoman Penyusunan Anggaran Pendapatan dan Belanja daerah Tahun Anggaran 2014 untuk melaksanakan program dan kegiatan yag bersumber dari bantuan keuangan Provinsi yang sudah jelas peruntukannya dan kegiatan dalam keadaan darurat dan mendesak lainnya yang belum cukup tersedia dan belum dianggarkan dalam APBD, dilakukan dengan merubah Peraturan Walikota tentang Penjabaran Anggaran Pendapatan dan Belanja Daerah.

Undang-Undang Nomor 17 Tahun 2003 tentang Keuangan Negara (Lembaran Negara Republik Indonesia Tahun 2003 Nomor 47, Tambahan Lembaran Negara Republik Indonesia Nomor 4286). Undang-Undang Nomor 1 Tahun 2004 tentang Perbendaharaan Negara (Lemabaran Negara Republik Indonesia Tahun 204 Nomor 5, Tambahan (Lemabaran Negara Republik Indonesia Nomor 4355). Undang-Undang Nomor 15 Tahun 2004 tentang Pemeriksaan Pengelolaan dan Tanggungjawab Keuangan Negara. Undang- 
Undang Nomor 33 Tahun 2004 tentang Perimbangan Keuangan antara

Pemerintah Pusat dan Pemerintah Daerah. Peraturan Pemerintah Nomor 24 Tahun 2005 tentang Standar Akuntansi Pemerintah. 


\section{BAB IV}

\section{SIMPULAN DAN SARAN}

\subsection{Simpulan}

Dari hasil pelaksanaan praktek magang dan setelah penulis menganalisa, memahami, dan mempelajari serta menguraikan masalah tentang Penyusunan Anggaran Belanja di lingkungan Dinas Pertanian (Distani), maka penulis mencoba menyimpulkan beberapa hasil kegiatan, yaitu :

1. Proses Penyusunan anggaran pada Dinas Pertanian dimulai pada bulan Juni-Juli dan berakhir pada bulan November-Desember. Pada Dinas pertanian penggunaan anggaran dibagi menjadi 2 (Dua) kelompok yaitu belanja langsung dan tidak langsung.

2. Yang menjadi dasar dalam pelaksanaan proses penyusunan anggaran belanja pada Dinas Pertanian adalah Renja (rencana kerja) yang berpedoman pada Peraturan Daerah Kota Bogor Nomor 5 Tahun 2010 tentang Rencana Pembangunan Jangka Menengah Daerah (RPJMD) Kota Bogor Tahun 2010 - 2014.

3. Dalam hal kesesuaian anggaran belanja pada Dinas Pertanian sudah sesuai dengan pedoman dan landasan hukum yang mengaturnya yaitu, Peraturan Daerah Kota Bogor, Peraturan Walikota, Peraturan Gubernur Jawa Barat, Peraturan Menteri Dalam Negeri. Walaupun ada beberapa kegiatan yang melebihi anggaran yang semestinya, dikarenakan oleh adanya pegawai yang memiliki kerja lebih (lembur). 


\subsection{Saran}

Setelah melaksanakan kerja praktek yang dilakukan di lingkungan lingkungan Dinas Pertanian, maka penulis berpendapat bahwa:

1. Proses penyusunan anggaran belanja di lingkungan Dinas Pertanian dilaksanakan sesuai dengan landasan berpendapat bahwa hukum yang mengaturnya dan instansi sebaiknya dapat terus mempertahankannya.

2. Terkadang dalam pelaksanaan anggaran belanja sering terjadi kurangnya penyerapan anggaran yang membuat realisasi anggaran di bawah pagu yang terkadang disebabkan oleh kurangnya SDM dan penghapus kegiatan di suatu bidang. Maka dari itu perlu adanya komunikasi dan koordinasi yang baik antar pihak yang terkait. Sehingga penganggaran belanja berjalan dengan baik dan tidak terjadi kurangnya penyerapan anggaran belanja. 


\section{DAFTAR PUSTAKA}

Departemen Keuangan, Dasar Hukum Anggaran, http://www.anggaran.depkeu.do.id (Diakses 9 Juli 2015)

Abdul Halim, 2007, Akuntansi Keuangan Daerah, Salemba Empat, Jakarta. Abdul Halim, Yanuar E. Restianto, Wayan Karman, 2010, Sistem Akuntansi Sektor Publik, Yogyakarta.

Deddi Nordiawan, 2006, Akuntansi Sektor Publik, Salemba Empat, Jakarta

Deddi Nordiawan, 2006, Akuntansi Sektor Publik, Edisi 2, Salemba Empat, Jakarta

Deddi Nordiawan. Ayuningtyas Hertianti, 2010, Akuntansi Sektor Publik, Salemba Empat, Jakarta

Indra Bastian, 2006, Akuntansi Sektor Publik Suatu Pengantar, Erlangga, Jakarta,

Indra Bastian. 2007, Sistem Akuntansi Sektor Publik, Edisi 2, Salemba Empat, Jakarta.

Madiasmo, 2009, Akuntansi Sektor Publik, Edisi 4, Andi Yogyakarta, Yogyakarta.

Mardiasmo, 2008, Akuntansi Sektor Publik, Edisi 2, Andi Yogyakarta, Yogyakarta

Muhammad Gade, 2005, Akuntansi Pemerintahan, Fakultas Ekonomi Universitas Indonesia, Jakarta

Munandar, 2008, Budgeting (Perencanaan kerja, pengkoordinasi kerja dan pengawasan kerja), edisi 2, BPFE Yogyakarta, Yogyakarta.

Nafarin, M, 2009, Penganggaran Perusahaan, edisi kedua, Salemba Empat, Jakarta

Rosjid, 2001, Akuntansi Sektor Publik, Aksara Satu, Surabaya.

Hakim, L. and Ariffin, M., 2013. Analisis Besaran Dividen Terhadap Besaran Laba Perusahaan. Jurnal Ilmiah Manajemen Kesatuan, 1(1), pp.61-70.

Setiawan, D.N. and Roestiono, H., 2014. Pengaruh Rasio CAMEL terhadap Tingkat Kesehatan Di Bank Tabungan Negara Syariah.

Prabowo, A. and Munawar, A., 2012. EVALUASI PENGELOLAAN MODAL KERJA SEBAGAI SARANA UNTUK MENGUKUR EFEKTIVITAS PERUSAHAAN DALAM MENGHASILKAN LABA. Jurnal Online Mahasiswa-Manajemen, $1(2)$.

Munawar, A., 2003. Penerapan Metode Peramalan Penjualan Sebagai Dasar Penetapan Rencana Produksi (Studi Kasus di PT Varia Industri Tirta). Jurnal IImiah Kesatuan, pp.1-2.

Rosita, S.I., 2012. Studi pembiayaan Mudharabah dan Laba Perusahaan pada PT Bank Muamalat Indonesia TBK. Cabang Bogor". Jurnal Ilmiah Kesatuan, Nomor, 1.

Fadillah, A., 2012. Biaya Saluran Distribusi Melalui Kanvas Dan Pengaruhnya Terhadap Volume Penjualan. Jurnal IImiah Kesatuan (JIK), 14(1).

Sulistiono, S., 2012. PENGARUH PERSEPSI BUNDLING PRICING SEBAGAI PENUNJANG KEPUTUSAN PEMBELIAN DALAM SUDUT STATUS SOSIAL CUSTOMER (STUDI KASUS PADA PT. FORMEBASIC). In 2012 marketing symposium, 1 (1).

Rusmiyati, R. and Sumantri, S. 2014. TINJAUAN PEMBERIAN PEMBIAYAAN DENGAN JAMINAN Studi Kasus pada PT. Bank Syariah Mandiri Kantor Cabang Pembantu Tajur. Jurnal Online Mahasiswa-Manajemen, 1(2).

Oktaviani, I. and Suharmiati, S., 2013.PROSEDUR PEMBERIAN KREDIT MULTI GUNA (KMG) TERHADAP GOLONGAN PENGHASILAN TETAP Studi kasus pada PT. Bank Rakyat Indonesia (Persero) Tbk. Cabang Bogor Dewi Sartika. Jurnal Online Mahasiswa-Manajemen, 1(2). 
